Historic, Archive Document

Do not assume content reflects current scientific knowledge, policies, or practices. 


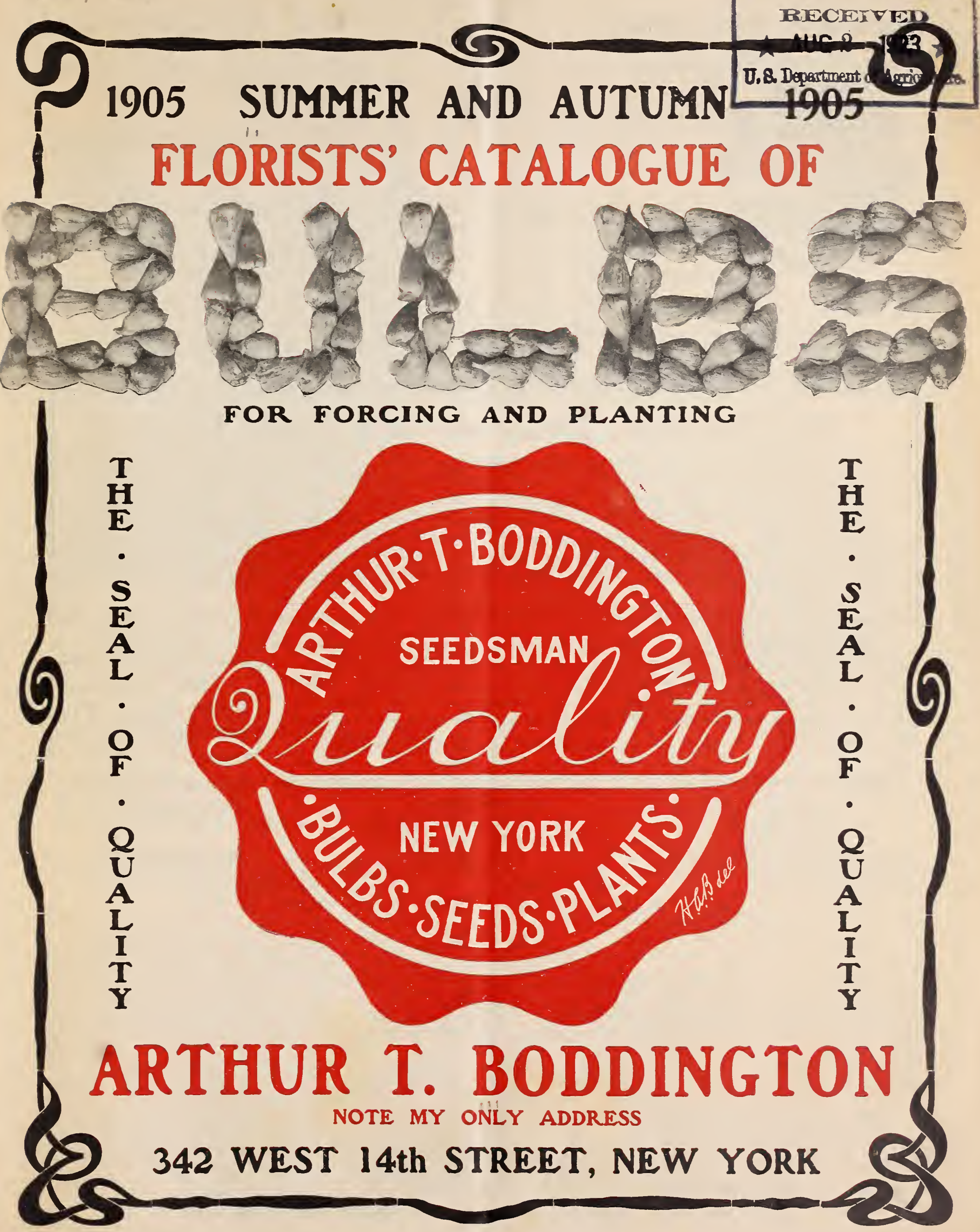




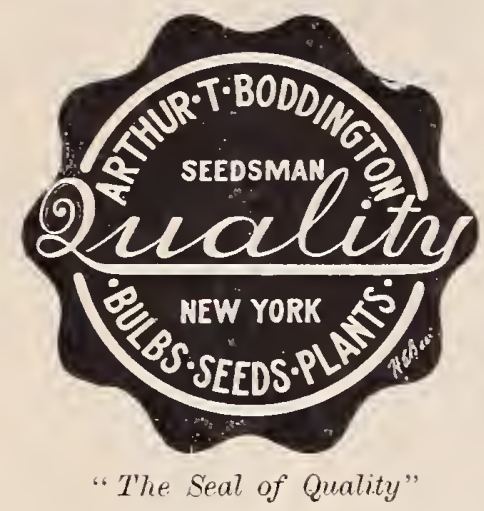

\section{MY TERMS}

Prices named herein are subject to the following discounts: Five per cent. allowed, to be deducted when cash accompanies order. To customers of approved credit, accounts are payable 60 days from date of invoice, except where special prices and terms are arranged for. Grass, Grain, Clover Seed, Implements, Fertilizers and Insecticides, are subject to no discount whatever, but are strictly net cash.

ORDERS are filled promptly upon receipt or a reason given with acknowledgment of same. Note below when the different kinds are ready.

PRICES. As it is impossible to predict the exact demand, my prices are made subject to change without notice, and goods being unsold when order reaches me. I, howerer, carry very large stocks, and if orders reach me in good season, full satisfaction may always be expected.

C. O. D. orders can be sent only by express. Such orders should be accompanied by a remittance in part payment, to guarantee charges.

\section{Per Cent. Reduction in Express Rates}

Under the ruling of the leading express companies, Plants, Bulbs and Seeds, packed in closed boxes or baskets, will now be carried at the "GENERAL SPECIALS" rate. This rate means a reduction of 20 per cent. from the regular merchandise rates to all points where no "General Specials" exists. To points where a "General Specials" rate is in force, the companies make a special reduction. Shipments weighing less than 100 lbs. receive the benefit of the rate per 100 lbs., but the minimum charge is 35c. For instance, where the regular merchandise rate is $\$ 4.00$ per 100 lbs., a box of plants or bulbs weighing 100 lbs. will be carried for $\$ 3.20$, a saving of 80c. on one shipment.

NON-WARRANTY.

I give no warranty, express or implied, as productiveness or any other matter of any seeds, bulbs or plants I send out, nor do I guarantee the successful flowering of seeds, bulbs or plants, or that the same will be free from disease. If not accepted on these terms the goods must be returned at once, and any money that has been paid for same will be refunded.
ARTHUR T. BODDINGTON. to description, quality, When comparing prices always com. pare the Quality, too

\section{Months of the year at which the different bulbous Stocks are ready for shipment and delivery \\ JULY \\ SEPTEMBER \\ NOVEMBER}

Harrisii, Freesias.

\section{AUGUST}

Roman Hyacinths, Paper White varcissus, White Callas and Buttercup Oxalis.
Lilium Candidum. Hyacinths, Tulips, and other Dutch Bulbs.

\section{OCTOBER}

Lilium Longiflorum and other Japan Lilies.
Spiræa, Lily of the Valley.

\section{DECEMBER}

New Crop of Tuberoses, Begonias, Gloxinias, Cannas, etc. April 15

\begin{tabular}{|c|c|c|c|}
\hline PAGE & PAGE & PAGE & PAGE \\
\hline Acacia Pubescens......... 14 & Florists' Sundries... & Lawn Grass Seeds. . Back Cover & Ornithogalum ............ \\
\hline Allium ................ 11 & Flower Seeds .......... & Leucojum............. 11 & Oxalis................ 10 \\
\hline Amaryllis ............ 10 & Freesia Refracta Alba.. & Lilacs............... $1 \pm$ & Pæonia Officinalis........ 10 \\
\hline Anemone. ............ 11 & 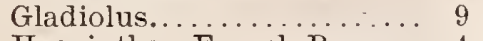 & Lilium Harrisii............ & Chinensis . ........... 11 \\
\hline Antirrhinum ........... 13 & Hyacinths-French Roman. & Longiflorum Multiflorum. & Pansies............... 12 \\
\hline Azalea Mollis ......... . . . 14 & White Italian .......... & " Giganteum. & Palm Seeds........... . . 13 \\
\hline Begonia, Gloire de Lorraine 14 & Dutch Roman............. & Candidum............. & Ranunculus ............ 11 \\
\hline Calla Lilies. . . . . . . . . . . 9 & Extra First Size Named & Auratum............... & Rhodanthe Manglesi....... 13 \\
\hline Chinese Sacred Narcissus.. & Dutch Hyacinths ......4, 5 & Speciosum Album....... & Roses................ 14 \\
\hline Chionodoxa ............ 11 & Second Size...........4,5 & " Rubrum...... & Schizanthus.......... 13 \\
\hline Cineraria. ............ 12 & Special Mixed...... & Lilium Melpomene........ 3 & Scilla............... 11 \\
\hline Crocus............... 9 & Insecticides.......... 15 & Lily of the Valley . . . . . . . 10 & Snowdrops............. 11 \\
\hline Cycas Revoluta........... 11 & Irises $\ldots \ldots \ldots \ldots \ldots \ldots \ldots$ & Manetti Stocks.......... 14 & Sparaxis............ 11 \\
\hline Cyclamen.............. 13 & Ixias $\ldots \ldots \ldots \ldots \ldots \ldots \ldots, 11$ & Mignonette.............. 13 & Spiræa, or Astilbe....... 9 \\
\hline Deutzia.... . . . . . . 14 & Japanese Fern Balls........ 11 & Montbretias............. 11 & Stocks ................ 13 \\
\hline Dielytra.............. 11 & Japanese Tea Paeonias..... 11 & Mushroom Spawn......... 15 & Sweer Peas. $\quad \ldots \ldots \ldots \ldots \ldots 13$ \\
\hline Fertilizers.............. 15 & Jonquils ............. 8 & Narcissus.............. & Tulips........ . . . . \\
\hline
\end{tabular}




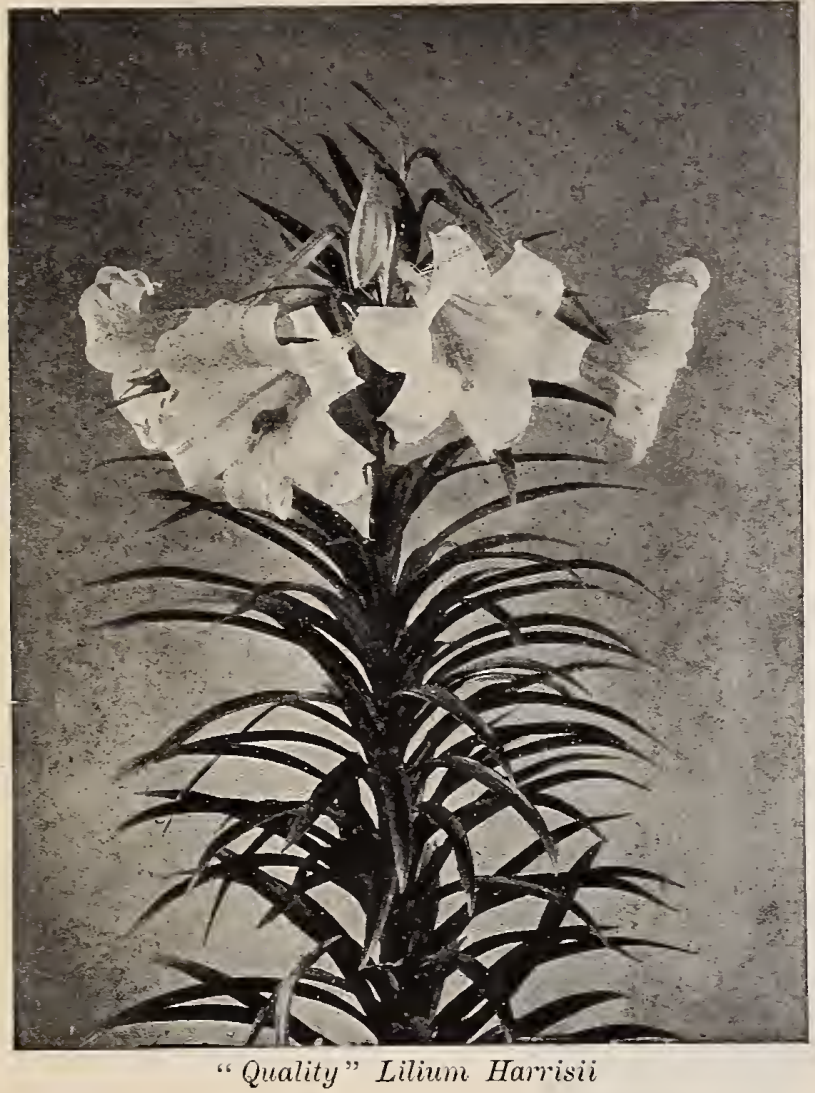

\section{LILIUM LONGIFLORUM MULTIFLORUM}

(Japan-Grown)

The standard Lily most florists depend upon for Easter flowering. Bulbs ready for delivery in October.

QUALITY BRAND 100

$6-8$-inch, 500 bulbs in a case . . . . \$3 50

$7-9$ ، 300 ،

1000

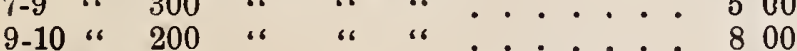

$\$ 3000$

4500

Monster, 100 " “ " ،

\section{LILIUM LONGIFLORUM GIGANTEUM \\ (Japan)}

The dark-stemmed variety with extra large flowers. To grow successfully for Easter blooming, keep at a slightly higher temperature and shade partially during growth to secure plants running 3 to $31 / 8$ feet high.

6-8-inch, 500 bulbs in a case. $\$ 420$

$7-9$ “ 300 " "

1000

$9-10$ “ 200 “ “

\section{LILIUM CANDIDUM}

(St. Joseph's or Annunciation Lily)

The thick-petaled kind, 22 centimeters and up in circumference. September delivery. $\$ 5.00$ per 100 ; $\$ 45.00$ per 1000 . About 250 in a case.

\section{LILIES}

True Bermuda Easter Lily

\section{LILIUM HARRISII}

Undoubtedly the best winter-blooming Lily in existence, and be so easily handled that it may be had in bloom by a succession from Thanksgiving Day until Easter. My Quality Brand tains a very much smaller proportion of diseased bulbs than se usually sent to the Now York market, and they are the True Harrisii type unmixed with Hybrids and Lilium longiflorum. Bulbs ready for delivery in August.

\section{QUALITY BRAND HARRISII}

7 -inch, 400 bulbs in a case ....... $\$ 450$

" 200 " " "

$\$ 4000$

17500

\section{CAN SUPPLY OTHER GRADES OF LILIUM HARRISII} AT "MEET COMPETITION PRICES"

\section{HARDY JAPAN LILIES}

For late Fall and spring delivery.

LILIUM AURATUM

(Golden-Rayed Lily of Japan)

$8-9$-inch, 130 bulbs in a case $\$ 100$

$9-11$ “ 100 "، " "

$11-13$ ، 75 ، “ “

\section{LILIUM MELPOMENE}

Very rich crimson.

(Superior form of Lilium Rubrum)

8 -9-inch, 160 bulbs in a case..... $\$ 600$ $9-11$ “ 100 “ “ “ . . . \$6 80

\section{LILIUM SPECIOSUM ALBUM}

(White Lancifolium Lily) 100

8-9-inch, 150 bulbs in a case .... \$ $\$ 700$ $9-11$ “ 100 “ “ “ . . . 1350 11-inch and over, 75 bulbs in a case... 1750

LILIUM SPECIOSUM RUBRUM (Rose Lancifolium Lily) 100 8-9-inch, 160 bulbs in a case ...... \$500 $\$ 4700$ $9-11$ “ 100 " “ " $850 \quad 8000$ 11 -inch and over, 75 bulbs in a case . . . 125011000

ALL MY JAPAN LILIES ARE RE-INSPECTED AND REPACKED BEFORE SHIPPING 


\section{HYACINTHS}

\section{FRENCH ROIMAN HYACINTHS}

Romans are an indispensable flower for funeral work from Thanksgiving until Easter. I import only high-class stock of even grade, well ripened bulbs. Early delivery my specialty when so desired.

"QUALITY BRAND" ROIVANS

White, 12 to 15 ctms., "Quality Brand" only, 2000 bulbs in a case ....... $\$ 275 \quad \$ 2400$

“ 13 to 15 ctms., "Quality Brand" only, 1750 bulbs in a case ..... 300

Light Pink Romans, 12 to 15 ctms. . . . 300

Dark "6 " 12 to 15 ctms.... $300 \quad 2300$

Dark Blue "6 12 to 15 ctms. . . . $300 \quad 2300$

\section{DUTCH ROIVAN HYACINTHS}

\section{3 to 15 ctms.}

These are small bulbs, or miniature Dutch Hyacinths, largely used for growing in pans or pots. They are also used extensively for bedding purposes. Named sorts, as follows :

Gertrude. Rosy pink ........

Gigantea. Daybreak-pink ......

Charles Dickens. Fine rose......

a Grandesse. Pure white . . . . . . 1001000

L'Innocence. White; one of the best . . $\$ 2 \quad 50 \quad \$ 2250$

Blanchard. White - Best a b i

Mme. Van der Hoop. Best late white

Grand Maitre. Deep porcelain blu

Czar Peter. Light porcelain blue. .

Queen of the Blues. Sky-blue; very fine.

Colors Separate. White, pink, red, light

and dark blue and yellow......

$225 \quad 2000$

\section{WHITE ITALIAN HYACINTHS \\ Or Pink-Skinned Romans}

These bloom later than White Roman and for that reason are valuable for succession. The flower spike is very fine. 13 to 15 ctms., $\$ 3.00$ per $100 ; \$ 22.00$ per 1000 .
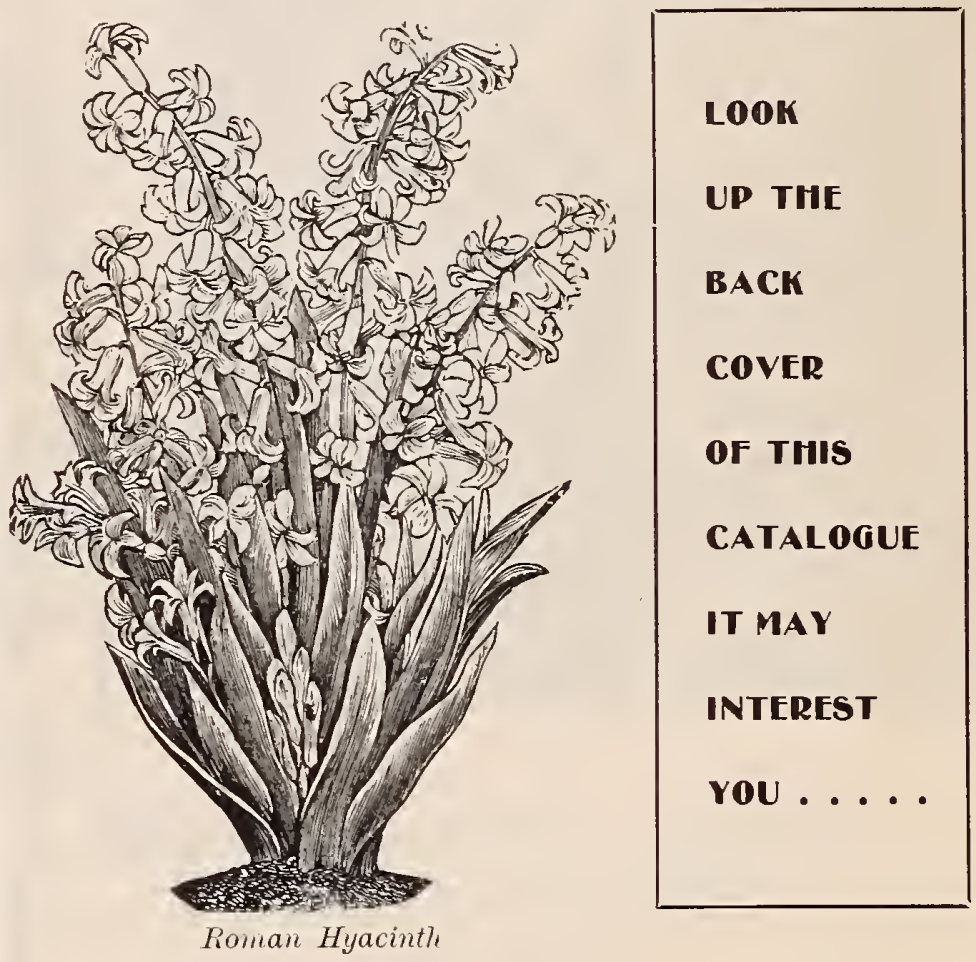

\section{SELECTED NAMED DUTCH HYACINTHS}

Don't be misled by Low Offers and Cheap Prices if you are looking for results

I buy only the very best goods in the following. Intending purchasers can rely upon all bulbs being thoroughly ripened, fully up to specified size and "quality," and true to name. I offer three sizes-First, Second and Named Bedding. These are standard Holland sizes. I do not buy seconds and send out as first size, and named bedding and send out as second size, which device is usually practiced by firms who make rldiculously low prices. You can rely upon my goods.

Extra Selected First Size Named Dutch Myacinths, in a General Selection . . . . $\$ 100$ Extra Selected Second Size Named Dutch Hyacinths, in a General Selection. . . 75

\section{SINGLE WHITE AND TINTED}

Albertina. Pure white; very fine .

Alba Suberbissima. Pure white, good spike $\cdots \cdots$

Baroness Van Thayll. Pure white, large truss . . . . . . . . . . .

British Queen. Very fine, pure white . . . . . . . . . . . . .

Grandeur a'Merveille. Finest blush white, immense truss . . . . . . .

Grand Vedetfe. Pure white, large bells; early . . . . . . . . . . . . .

Innocence. Pure white; extra large

La Grandesse. Finest pure white, large bells . . . . . . . . . . . .

Mme. Van der Hoop. Pure white, large truss; dwarf; late .......

Queen Vicforia. Pure white, fine spike . . . . . . . . . . . . .

Reine de Molland. Pure white, fine spike; early ...............
Fixtra selected first size bulbs

Per 12

Por 12
$\$ 125$

100

100

125

100

10 on

125

125

125
$\$ 800$

750

725

800

725

700

800

800

800

\begin{tabular}{rrrr} 
& \multicolumn{1}{c}{$r$} & & 1000 \\
$\$ 7$ & 50 & $\$ 70$ & 00 \\
5 & 50 & & 5000
\end{tabular}

Extra selected second size bulbs Per 12 \$0 $85 \$ 600$

75

500

75

65

500

450

600

600

600

600

450 


\section{FIRST AND SECOND SIZE DUTCH NAMED HYACINTHS-Continued}

\section{SINGLE RED, ROSE AND PINK}

Baron Van Thuyll. Flesh color, compact spike; very early . . . . . . . . Charles Dickens. Fine rose, large spike; extra . . . . . . . . . . . . . . . Fabiola. Pink, carmine striped; fine

General Pelissier. Deep crimson, fine truss; early . . . . . . . . . . . .

Gertrude. Rosy pink, compact truss . . . . . . . . . . . . . . .

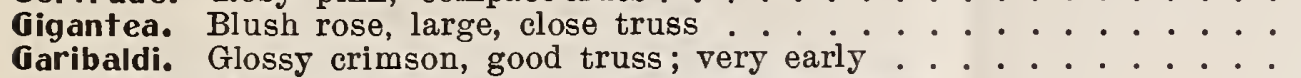

Lord Macaulay. Bright rose carmine, splendid truss . . . . . . . . . . . .

Moreno. Waxy pink, large bells and truss . . . . . . . . . . . . . .

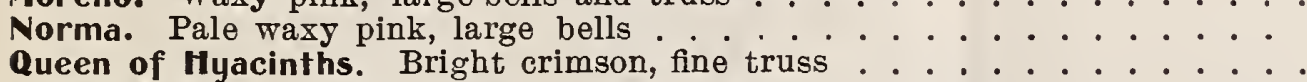

Robert Steiger. Deep crimson, large truss . . . . . . . . . . . . . .

Roi des Belges. Fine deep red

Sultan's Favorite. Blush pink, shaded

SINGLE BLUE AND PURPLE

Baron Van Thuyll. Deep violet blue, good truss; early . . . . . . . . . . .

Charles Dickens. Porcelain blue, shaded purple, large spike.......

Czar Peter. Light porcelain blue, lighter center, grand truss . . . . . . .

Grand Maitre. Deep porcelain blue, large truss and bulb; extra $\cdots{ }_{1}$

King of the Blues. Rich dark blue, splendid, well-finished truss ...... 100

La Peyrouse. Clear porcelain blue

Leonidas. Bright blue; early. . . . . . . . . . . . . . . . . 100

Marie. Deep blue, large truss and bulb . . . . . . . . . 100

Prince of Wales. Purplish velvet blue, with pure white eje. . . . . . . 100

Queen of the Blues. Porcelain sky-blue, very large bells and fine spike . . . 110

Regulus. Porcelain blue, large bells

SINGLE YELLOW AND ORANGE

Bird of Paradise. Pure yellow, compact spike . . . . . . . . . . . .

Hermann. Orange-yellow, large spike . . . . . . . . . . . . . . . .

Ida. Pure light yellow, large truss; early . . . . . . . . . . . . . . .

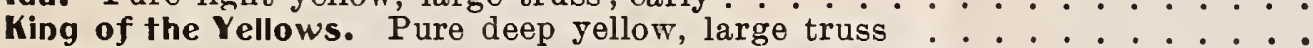

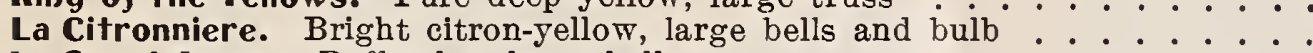

Le Grand Jaune. Buff color, large bells..................... 100

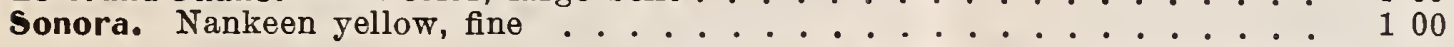

DOUBLE WHITE AND TINTED

Bouquet Royal. Pure white, jellow center, good truss . . . . . . . . .

Duchesse de Bedford. Pure white, large bells and truss . . . . . . . . . . . . 100

La Tour d'Auvergne. Pure white, good bells, large truss; extra ....... 100

La Virginite. Blush white, large bells, fine spike............ 100

Prince of Waterloo. Pure white, fine truss, large bells . . . . . . . . .

Princess Alice. Snow white, dwarf

DOUBLE RED, ROSE AND PINK

Bouquet Royal. Rose, dark center, good spike . . . . . . . . . . . . Czar Nicholas. Delicate rose; early .

100

100

100

100

Disraeli. Very fine pink

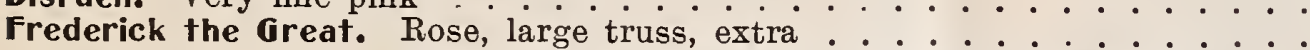

Le Grand Concurrent. Beautiful pale rose, large bells and truss; extra . .

Lord Wellington. Delicate rosy blush, large bells and truss; one of the best .

Princess Louise. Deep red, large flower

Regina Victoria. Fine salmon-rose, good bells

100

100

DOUBLE BLUE AND PURPLE

Blocksberg. Pale porcelain blue, grand

Bride of Lammermoor. Dark blue, striped lilac, dark center $. . . . \quad . \quad . \quad . \quad$.

Charles Dickens. Dark blue, extra large spike . . . . . . . . . . . . . . . .

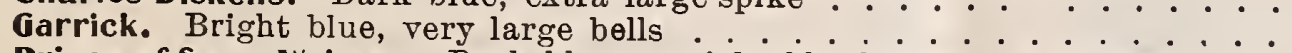

Prince of Saxe-Weimar. Dark blue, semi-double, large truss; early.$\cdots$
Van Speyk. Light blue, large bells and truss..

DOUBLE YELLOW

Goethe. Light yellow, large bells, fine spike

DOUBLE YELLOW

Jaune Supreme. Deep yellow, salmon tinted

Minerva. Orange-red and salmon, fine bells, compact spike $\dot{*}^{*} \cdot \bullet^{*} \cdot \cdot$

William iI. Fine yellow, large and early

NOTE MY ONLY ADDPESS

100

100

100

100

$\begin{array}{ll}6 & 50 \\ 6 & 50\end{array}$

tra selected

rst size bulbs
12 Per 100

25

00

15

00

25

00

$\$ 800$

700

700

750

750

800

700

700

800

700

675

Extra selected Extra selected
second size bulbs $\begin{array}{ll}\text { second size bulbs } \\ \text { Per } 12 & \text { Per } 100\end{array}$ $\$ 065 \quad \$ 450$

$\begin{array}{ll}65 & 450 \\ 75 & 500\end{array}$

75

75

80

80

75

65

75

$\begin{array}{ll}5 & 00 \\ 5 & 00\end{array}$

$\begin{array}{lll}5 & 00 \\ 5 & 00\end{array}$

550

$\begin{array}{ll}5 & 50 \\ 5 & 00\end{array}$

450

500

65

450

\begin{tabular}{|c|c|c|}
\hline 725 & 65 & 450 \\
\hline 800 & 85 & $\begin{array}{ll}5 & 00 \\
6 & 00\end{array}$ \\
\hline 800 & & \\
\hline 725 & 80 & 550 \\
\hline 700 & 75 & 500 \\
\hline & 65 & 450 \\
\hline 700 & 75 & 500 \\
\hline 700 & 65 & 450 \\
\hline 700 & 80 & 600 \\
\hline 725 & 80 & 550 \\
\hline & 80 & 550 \\
\hline
\end{tabular}

800

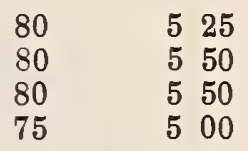

$\begin{array}{ll}7 & 00\end{array}$

700

$\begin{array}{ll}7 & 00\end{array}$

700

650

700

650

700

800

700

625

\section{0}

80
80

80

50




\section{Named Bedding or Forcing Hyacinths} Sold by some Seedsmen as Second Size

\section{BODDINGTON'S “QUALITY”}

These are a superior grade of bedding hyacinths, being large-sized named bulbs of 17 centimeters and over. For size of flower and general effect when massed in beds they are unsurpassed.

These bulbs are offered to name and color. My selection of varieties, single and double.

\section{$\$ 4.00$ per 100; \$35.50 per 1000}

\section{SPECIAL MIXED HYACINTHS FOR BEDDING OR FORCING}

The bulbs have been specially selected in Holland for me, and are equally suited for either bedding or forcing. They will all throw large uniform spikes of flowers, and cannot fail to give universal satisfaction.

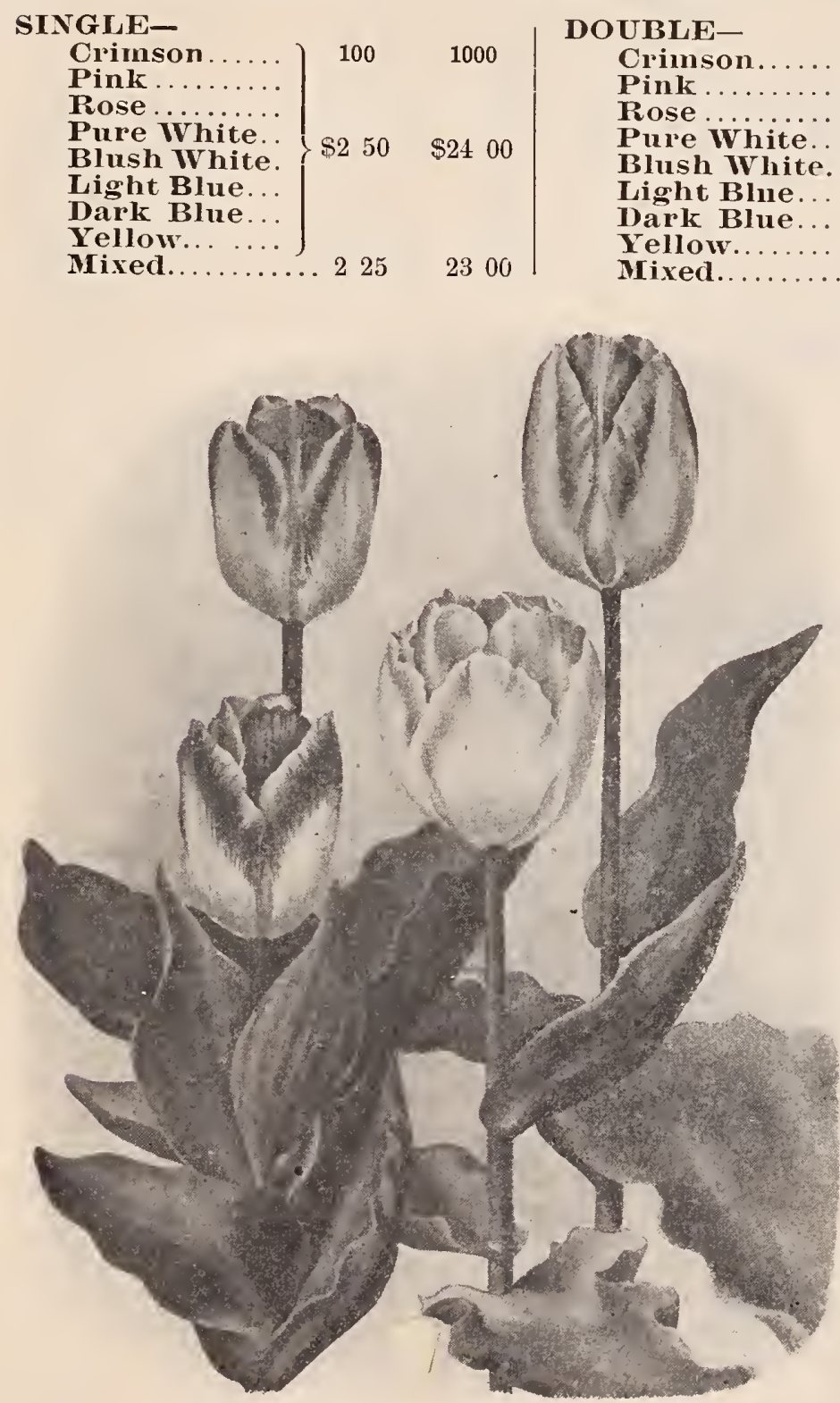

Iulips, Single-Proserpine, Keizerskroon, Yellow Prince, Cottage Maid
$100 \quad 1000$

$275 \quad \$ 2500$

250

2400

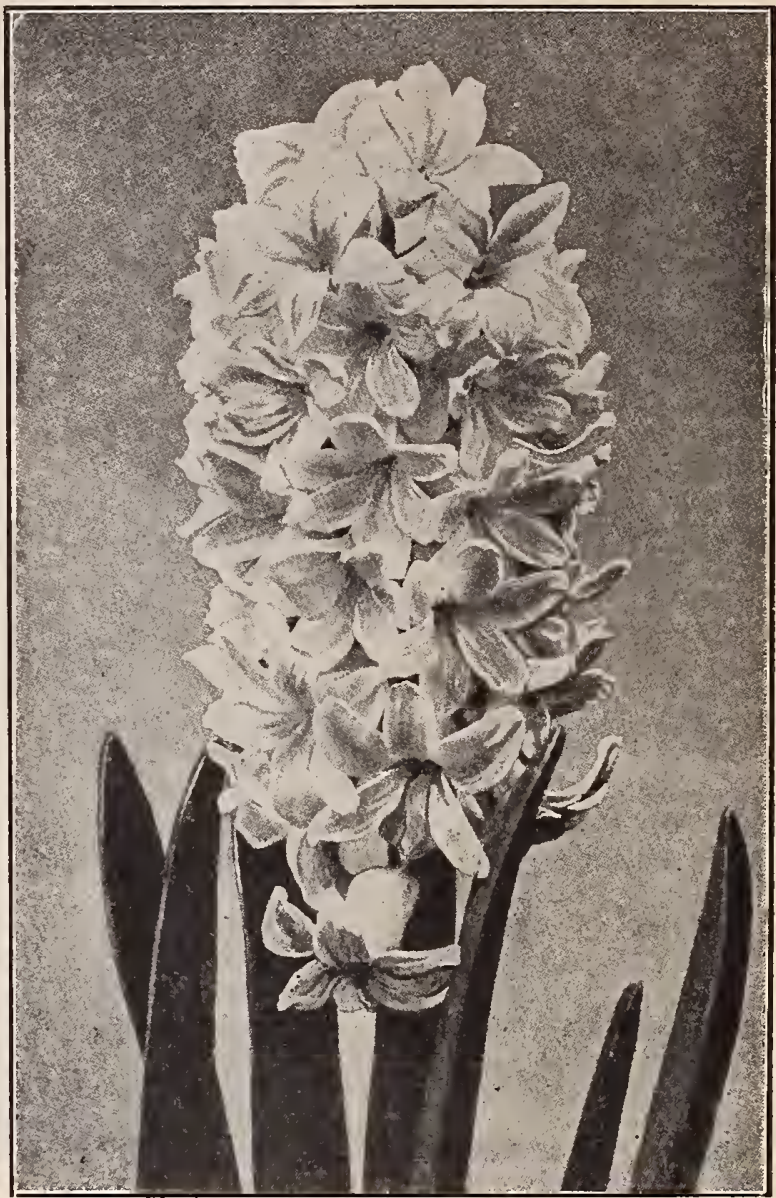

Irutch Hyacinth La Grandesse

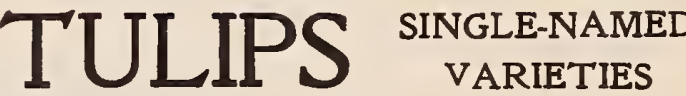

\section{All First-Size Flowering Bulbs Only}

Artus. Dark scarlet.

$100 \quad 1000$

Aelle Alliance Scarlet, good bedder .......\$1 $15 \quad \$ 1050$

Bizard Verdict, Orange-yellow and brown... $85 \quad 750$

Brutus. Orange-crimson, good forcer....... . $125 \quad 925$

Cardinal's Hat, Dark red................. $90 \quad 750$

Chrysolora. Pure yellow, handsome flower... $95 \quad 800$

Coulenr Ponceau. Rich cerise, very fine.... $85-700$

Cottage Maid. Rosy pink, white striped;

excellent forcer. "Quality Brand.".......... 85

Cramoise Brilliant. Bright scarlet, excellent

forcer. Bur. 200

Couleur Cardinal. Crimson-scarlet, very

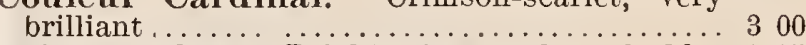

Crimson King. Bright erimson, showy bedder 115

Duc Van Thol. Red and yellow............ 100

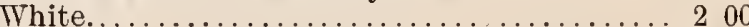

Scarlet...................................... 110

Rose...................................... 225

Yellow .................................. 200

Duchesse de Parma. Orange-red, yellow

shaded, very large flower................. 85

Joost Van Vondel. Cherry red, feathered white 115

Keizerskioon. Red with broad yellow edge,

large and very effective................. 125

King of the Yellows. Deep golden yellow... 125

La Reine. White, slightly rose shaded; good

forcer and bedder. "Quality Brand."......... 75

L'Immaculee. Pure white; good forcer; early. $\quad 75$
850

1950

2800

1050

925

1600

1000

1900

1900

750

1050

1200

1200

700

650 


\section{TULIPS-Continued}

100 cup; very handsome and good

$\$ 200 \$ 1500$

Pottebakker Scarlet. Bright scarlet; good forcer and bedder: very flne.

Pottebakker Yellow. Large bright yellow, red tinged; good forcer

Pottebakker ivhite. Pure white, large showy flower splendid for forcing .......... 13 5

Princess Marianna. Large,

white, slightly red striped...... 100

Prince of Austria. Brilliant orange vermilion, large flowers; fine for forcing ........... 275

P roserpine. Large and handsome, rich, silky rose; early forcer...................... 275

Rose Grisdelin. Delicate pink, tinged white; good forcer; very

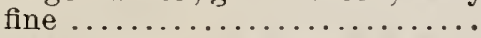

Rosamundi Huyckman. Bright pink, feathered white; very large flowers...............

Rose Lnisante. Deep pink; a high-class showy variety .... $300 \quad 2850$

Standard, or Royal Silver. Thite and crim- $100 \quad 1000$ son; very effective ................... $\$ 150 \quad \$ 1150$

Thonns Moore. Apricot orange; fine for var-

iety...................... $125 \quad 1025$

Vau Gooyen. Rosy white; good early forcer, though but little known................. $125 \quad 1050$

Vermilion Brilliant. Bright Scarlet and vermilion; excellent for pots and very showy bed-

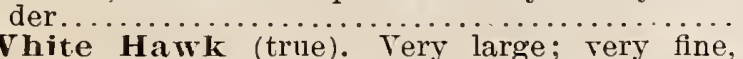

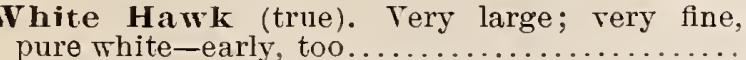

Yellow Prince. Pure vellow: one of the best yellows for bedding or forcing..

\section{SUPERFINE MIXED SINGLE TULIPS}

This mixture is made up of equal proportions of the best bedding tulips comprising a variation of color and shades that makes them very effective when massed in beds. $75 \mathrm{c}$. per $100, \$ 6.50$ per 1000 .

\section{FINE MIXED SINGLE TULIPS}

A mixture of good bedding tulips for planting, or selling orer the counter to your retail customers (see back corer). 60c. per $100, \$ 5.25$ per 1000 .

\section{DOUBLE TULIPS}

\section{ALL FIRST-SIZE BULBS ONLY}

Couronne d'Or (true). Sometimes sold as $100 \quad 1000$ "Crown of Gold." Yellow, tinged with old gold; one of the finest for forcing either for pot or pans.

Duc Van Thol. Red and rellow; rery earty and

dwarf.................................... $075 \quad 650$

Gloria Solis. A handsome flower; bronze red,

with yellow border; extra large............. 125

Imperator rubrorum. Handsome scarlet;

very showy and lasting.................... 275

La Candenr. Pure white; splendid companion to Rex rubrorum as a bedder ................

Murillo. Magnificent blush white; flowers are

rery large and early ................... 200

Rex rubrormm. Bright scarlet, showy and very

effective for bedding.................. 150

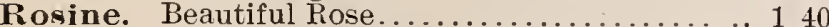

Salvator Rosa. Beautiful deep rose; striped

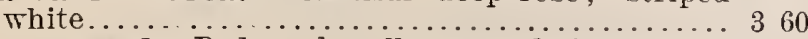

Tournesol. Red and yellow; good forcer and

Fery early.......................... 1

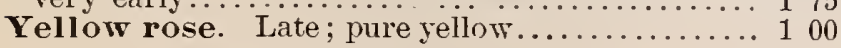

(2)




\section{PAPER WHITE NARCISSUS}

Paper White Narcissus Grandiflora with the florist is a staple article and an important item. To secure good results, only the best should be secured. My "Quality Brand" is true and free from the old type "totus albus" and other mixtures. I handle only one size, $13 \mathrm{ctms}$, and up, running about 1300 to the case. Price, \$1.25 per 100; \$9.00 per 1000.

Paper White Narcissus, when placed in shallow bowl-the same as Chinese Sacred Narcissus-will bloom freely and are an attractive novelty.

\section{PAPER WHITE GRANDIFLORA IULTIFLORA}

This variety is a great improvement over the grandiflora; a vigorous grower, with fine spike, which carries larger trusses, and in greater abundance than the old varieties. 14 ctms. and over, 1000 to the case. $\$ 1.50$ per 100 ; $\$ 12.00$ per 1000

\section{DOUBLE NARCISSUS, OR DAFFODILS}

\begin{tabular}{|l}
\hline Von Sion (True Double Daffodil). \\
\hline large fancy double-nosed bulbs,
\end{tabular}

Alba Plena Odorata (Gardenia-flowered Daffodil). Double $100 \quad 1000$ snow-white flowers; very sweet-scented; late flowering...... \$0 $75 \quad \$ 550$ Incomparable, fl. pl. (Butter and Eggs). Rich yellow and white, very double; good forcer or for outside.

Orange Phoenix (Bacon and Eggs). Beautiful white and orange Narcissus

90700

$100 \quad 850$

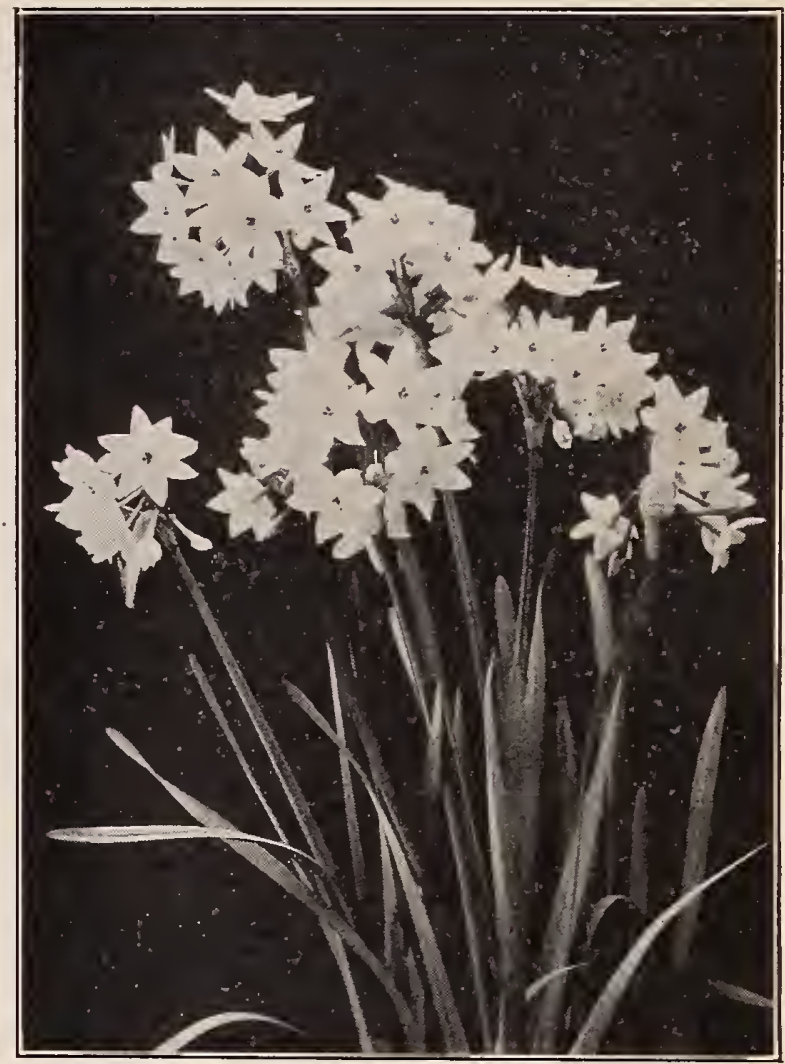

Narcissus Paper. White Grandiflora

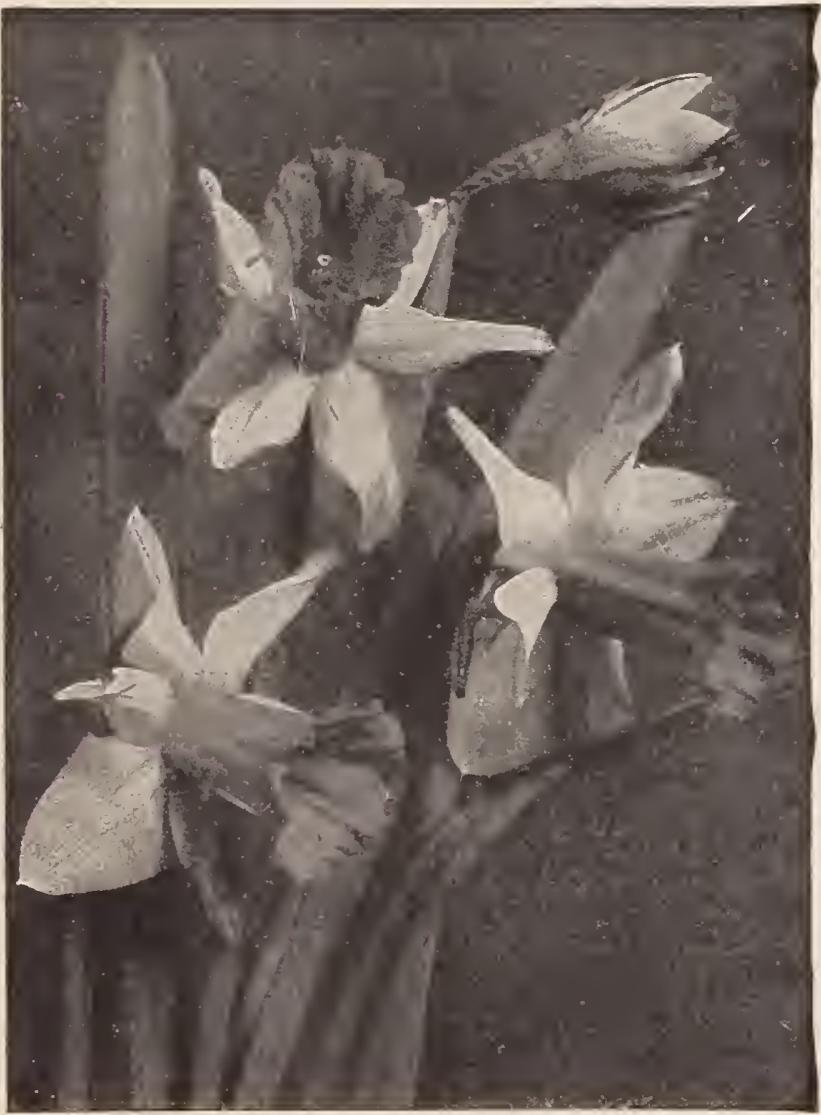

Trumpet Narcissus Horsefieldii From "How to Make a Flower Garden"

\section{SINGLE NARCISSUS}

Ajax Princeps. Very early; sulphur trumpet, white perianth; a popular forcing variety ....................

Emperor. The best single Narcissus; pure golden yellow, of

Empress. Pure white perianth, with rich yellow trumpet; a splendid variety.

Golden Spur. Deep yellow perianth and trumpet; very large; equally good as a forcer and for garden; extra selected bulbs, double-nosed.

Henry Ipving. Magnificent flower of the richest yellow, trumpet beautifully frilled; very early

Horsfieldii. Pure white, with yellow trumpet; the largest flower of its class, and very early.

Poeticus (Pheasant's Eye). Pure white flowers, orange cup, edged with orimson.

Poeticus Ornatus. An improved Poeticus; pure white perianth, distinct red crown; very early

Queen Victoria. A grand flower; pure white with yellow cup

Trumpet Major. Large flower, pure golden yellow; the best for early forcing..

$100 \quad 1000$

\section{JONQUILS}

Campernelle, Large yellow.

Rugulosus. Very fragrant; the largest Jonquil

Double Sweet-Scented. Fine deep yellow............. 100090

Single Sweet-Scented. Deep yellow, very free........... 55

\section{CHINESE SACRED NARCISSUS}

Per original basket of 30 bulbs, $\$ 1.25$; per mat of 120 bulbs, $\$ 4.50$ per 1000 , $\$ 35.00$ 


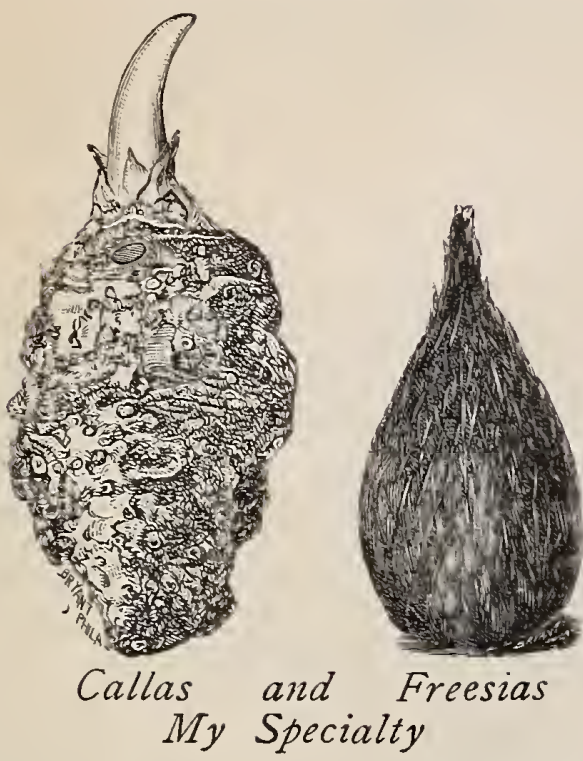

\section{FREESIA REFRACTA ALBA}

Bermuda-Grown "Quality Brand"

Large, selected bulbs.

Mammoth . .

.....................

\section{CALIFORNIA-GROWN}

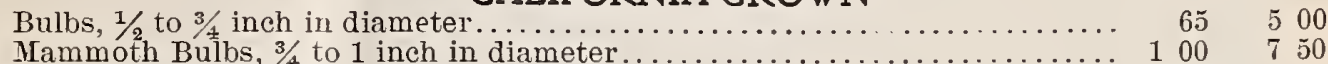

Bulbs, $1 / 2$ to $3 / 4$ inch in diameter

Monster bulbs, $3 / 4$ inch and up in diameter ......................... 1000450

\section{CALLA LILIES}

These bulbs have been selected with great care and are sound and free from rot. Bulbs ready for delivery in August.

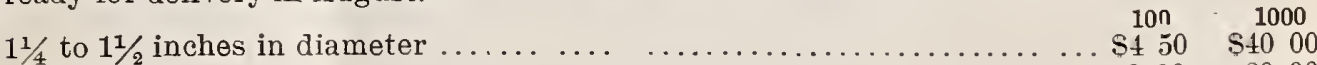

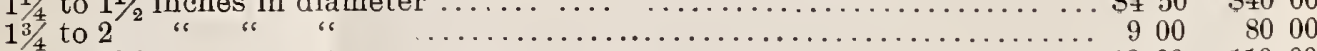
2 to $21 / 2$ ، " ،

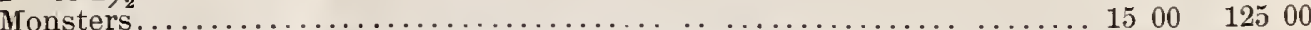

Spotted Leaf Calla (Alba maculata). Invaluable for bedding out in the open for summer blooming. $\$ 3.00$ per $100 ; \$ 25.00$ per 1000 .

\section{CROCUS (Large Bulbs)}

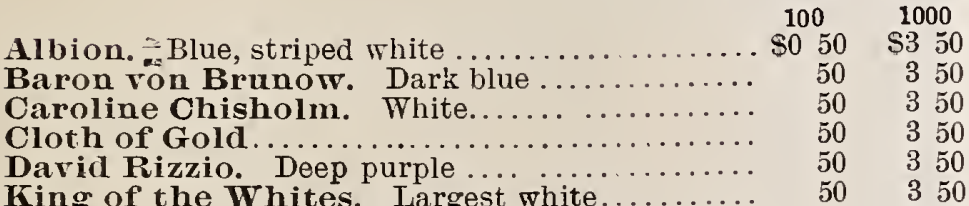

Madam Mina. : Striped

Mammoth Golden Yellow.

Mont Blanc. Pure white.

Sir Walter Scott. White, lilac striped

Mixed Crocus. Separate colors, white, striped blue, variegated, yellow.......

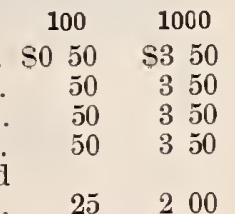

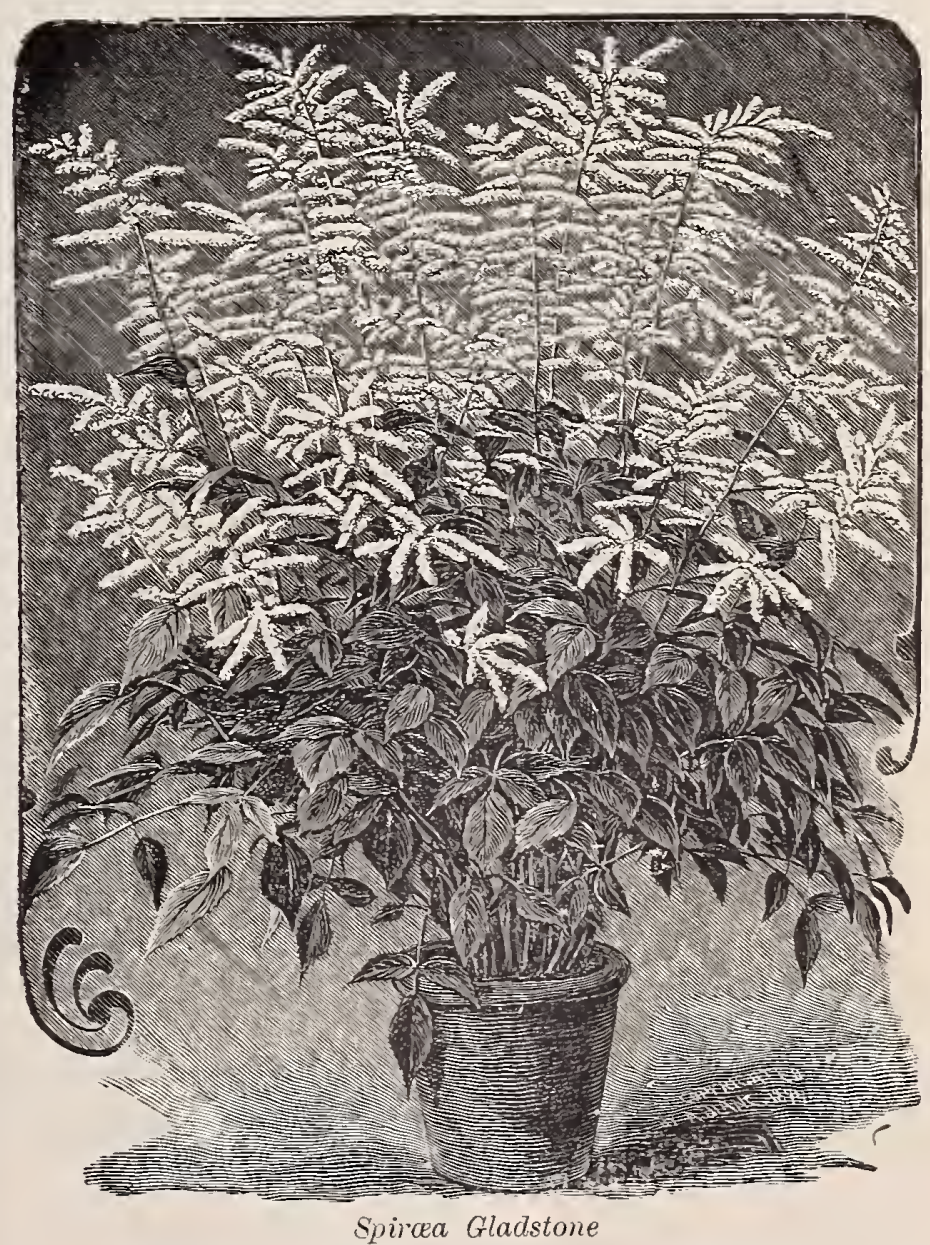

Gladstone. This new variety far excels the older kinds. Enormous spikes of pure white flowers, borne upon strong stems 18 inches high. The foliage is all that can be desired. $\$ 1.50$ per doz.; $\$ 10.00$ per 100 .

Washington. Another new variety of great beauty. Stems nearly two feet high. A handsome plant for decorative work. $\$ 1.75$ per doz.; $\$ 12.00$ per 100 .

Compacta multiflora. Good, compact variety; very shapely and excellent forcer. 75c. per doz.; $\$ 4.50$ per $100 ; \$ 10.00$ per 1000 .

Astilboides floribunda. A very strong grower, producing large, pure white plumes. 75c. per doz.; $\$ 1.50$ per $100 ; \$ 40.00$ ver 1000 .

Japonica. The old variety; perfectly hardy and good forcer. $\$ \pm .50$ per $100 ; \$ 10.00$ per 1000 .

Superbe. Makes a perfect plant for decorative purposes. Is an early and abundant flowerer, of a beautiful, symmetrical shape. The fiowers are pure white, borne on stiff stems; $1 \frac{1}{2}$ to 2 feet high. $\$ 1.00$ per doz.; $\$ 6.50$ per 100 . 


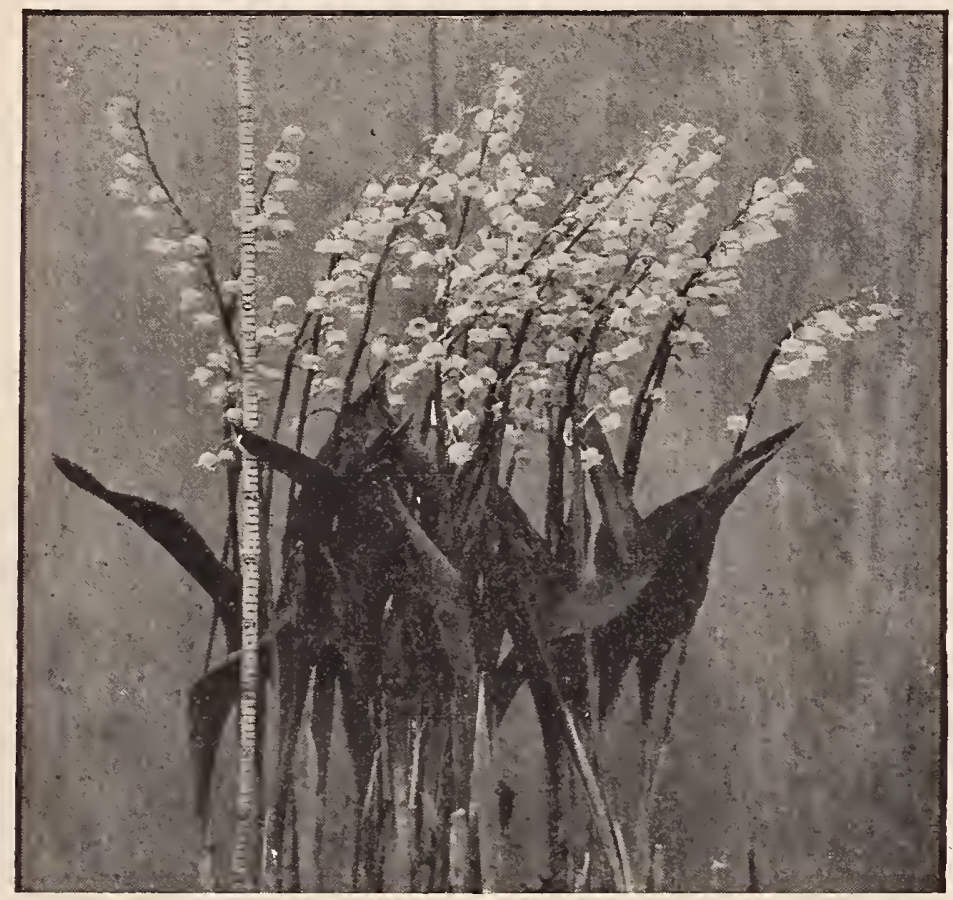

Lily of Valley, "Wedding Bells"

\section{JAPAN IRIS (Iris Kaempferi)}

\author{
(October Delivery)
}

Nothing can surpass the beauty of these magnificent flowers, which are of enormous size, averaging six to eight inches across. 'The colors are varied and give the bloom an orchid-like appearance. It is perfectly hardy and thrives best in moist soil, or when plentifully supplied with water. I offer these in 12 named varieties, single and double. $\$ 1.75$ per doz. : $\$ 12.00$ per 100 .

\section{SPANISH IRIS (Iris Hispanica)}

The true value of this Iris appears to have been overlooked in this country. The great diversity of color and its being equally adapted for gentle forcing and massing in beds make it one of the most useful bulbs to plant.

Alexander von Humboldt. Dark blue.

Belle Chinoise. Pure yellow.

Blanch Superb. pure white.

Blanch Fleur. White, with pale center.

Chrysolora. Pale yellow.

Darling. Blue, very fine; early.

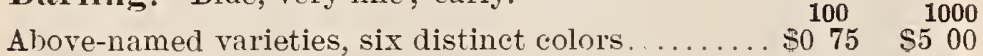

Mixed, all colors......................... $\quad 40 \quad 350$

\section{ENGLISH IRIS}

Large, handsome flowers.

Named varieties in 10 best sorts............... \$2 $50 \quad \$ 2000$ Mixed, all colors ............................. $125 \quad 1000$

\section{AMIARYLLIS}

Doz. $\quad 100$

Johnsoni (Bermuda Spice Lily). Very large bulbs $\begin{array}{llll}\$ 2 & 517 & 50\end{array}$ Formosissima (Jacobean Lily)................ $100 \quad 700$ Longifolia alba...................... $125 \quad 800$ rosea....................... $125 \quad 800$

Look up the back cover of this catalogue. It may interest you.

\section{LILY OF THE VALLEY}

(New Crop-December Delivery)

My "Wedding Bells" brand being specially selected, will convince the most critical grower of its superiority over most brands offered for early forcing, the foliage and flower spike being all that can be desired.

$\$ 1.75$ per $100 ; \$ 14.00$ per $1000 ; \$ 34.00$ per case of 2500 .

Quality Berlin Pips. Strong, three-year-old pips; a really good Valley.

$\$ 1.50$ per $100 ; \$ 12.00$ per $1000 ; \$ 29.50$ per case of 2500 .

Selected Hamburg Pips. Strong, three-year-old, for late winter and spring forcing.

$\$ 1.25$ per $100 ; \$ 10.00$ per $1000 ; \$ 24.50$ per case of 2500 .

Large Clumps of Lily of the Valley for outside planting. $\$ 2.50$ per doz.; $\$ 18.50$ per 100 .

\section{Lily of the Valley from Cold Storage}

I import large quantities of the best grade of Valley for forcing, which is put in cold storage immediately upon arrival and kept in perfectly dormant condition. These pips can be shipped at any season of the year and can be brought into full flower in three weeks from time of planting without undue forcing. $\$ 2.00$ per $100 ; \$ 15.00$ per $1000 ; \$ 35.00$ per case of 2500 .

\section{OXALIS}

Alba. White.................. $\$ 0^{100} 75 \quad \$ 600$

Bermuda Buttercup. Extra-sized bulbs.... $100 \quad 900$

Boweii. Rosy crimson, fine flower... .......... $80 \quad 700$

Grand Duchess. White.................... $100 \quad 900$ “.

Lavender......................... $80 \quad 700$

Lutea. Single Yellow..................... $75 \quad 600$ Double.............................. $125 \quad 1000$

Rosea. Rose........................... 65 . 500

Versicolor. Crimson and white.............. $75 \quad 600$

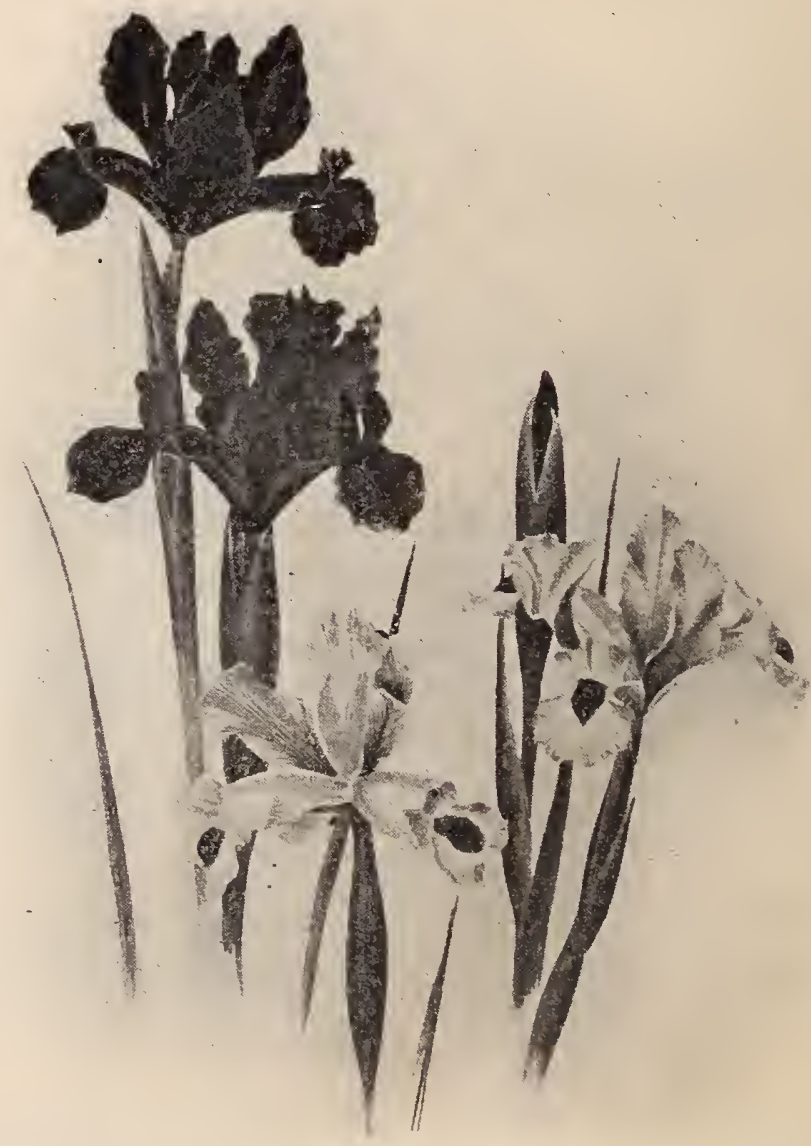

Iris, Spanish, in Variety 
The New Gigantic Orchid Flowering Cosmos

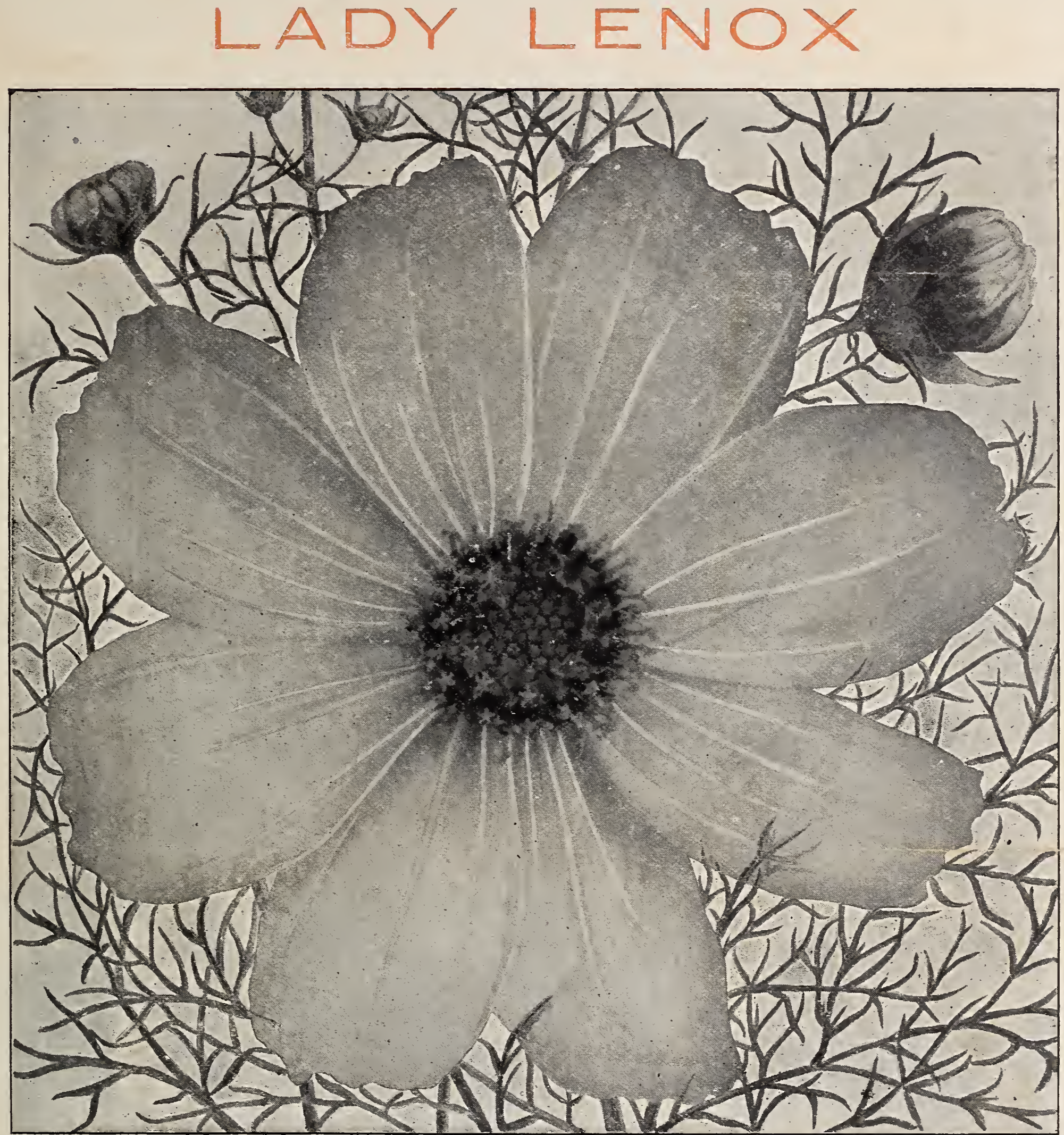

THIS GIGANTIC COSMOS is the forerunner of an entirely new race of Cosmos. It is of extraordinary size and beaty. Visitors to the floral exhibitions last autumn were enraptured with its size and magnificent color.

SIZE OF FLOWER-Six to Seven Inches in Diameter. COLOR. A delightful shell-pink, lighting up beautifully at night. FORM OF FLOWER. Oval petals of splendid substance, forming a perfectly circular flower which, when cut, lasts an unusual length of time in water. HABIT OF PLANT. Strong and vigorous, growing 6 to 7 feet high. Flowers may be cut with any length of stem up to 5 feet.

Under date of October 16, 1906, Messrs. C. C. Morse \& Co., Seed Growers, of San Francisco, California, write us as follows: "Your new Cosmos, Lady Lenox, is now in full bloom. We are pleased to say it is one of the handsomest varieties of Cosmos that we have ever seen. The flowers are very large and full and the color is a very beautiful light pink. We would be glad to know what price you would be willing to make us for a quarter of a pound."

We are the sole owners of this variety, which will be disseminated January, 1908, for the first time, and will offer it in our seed catalogues at both wholesale and retail at 25c. per package, 5 packets for $\$ 1.00$, and respectfully request that intending purchasers adhere to these prices.

At seasonable times, we shall carry full-page advertisements in the leading trade papers-stating that this variety can be obtained of all seedsman.

We will also have colored inserts printed in five colors, by J. Horace McFarland Co., which we will supply at cost to catalogue men and șeedsmen-prices and samples upon application.

\section{PRICE OF SEED TO THE TRADE}

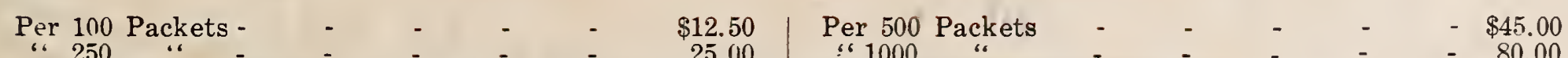

Any firm ordering 100 Packets, and buying more during the season, will be re-credited at above rates.

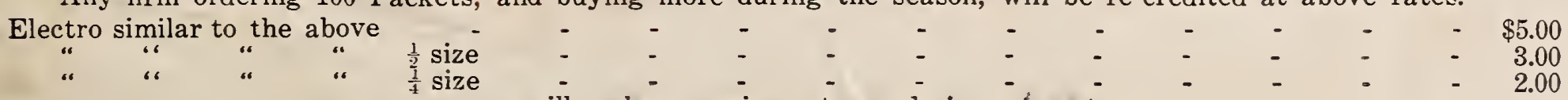

or will make any size cut you desire, at cost

Flowers of this Cosmos will be exhibited at all the leading flower shows in the United States, Autumn, 1907 



\section{ALLIUM}

Neapolitanum. An excellent forcer for winter flowering, with immense trusses of white flowers. 50c. per $100 ; \$ 4.00$ per 1000

\section{ANEMONE} Double, mixed...
Rich, dazzling scar

\section{CHIONODOXA}

Lucilia

DIELYTRA

Spectabilis (Bleeding Heart)-Norember delivery, 600

\section{IXIAS}

Named Varieties. In 10 best sorts

Mixed

\section{LEUCOJUM}

\section{MONTBRETIAS}

Crocosmæflora. Orange scarlet.

Etoile de Feu. Rich scarlet, yellow center.

Rayon d'Or. Deep yellow, very large.......

Pottsii. Bright yellow, flushed with red ......

Soleil Couchant. Bright red...

\section{ORNITHOGALUM}

Arabicum (Star of Bethlehem)

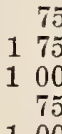

175

100

100
800 1500
Coronaria. Single mixed

Vernum (Spring Snowflake).

\section{RANUNCULUS} 1200 dozen; $\$+0.00$ per 100

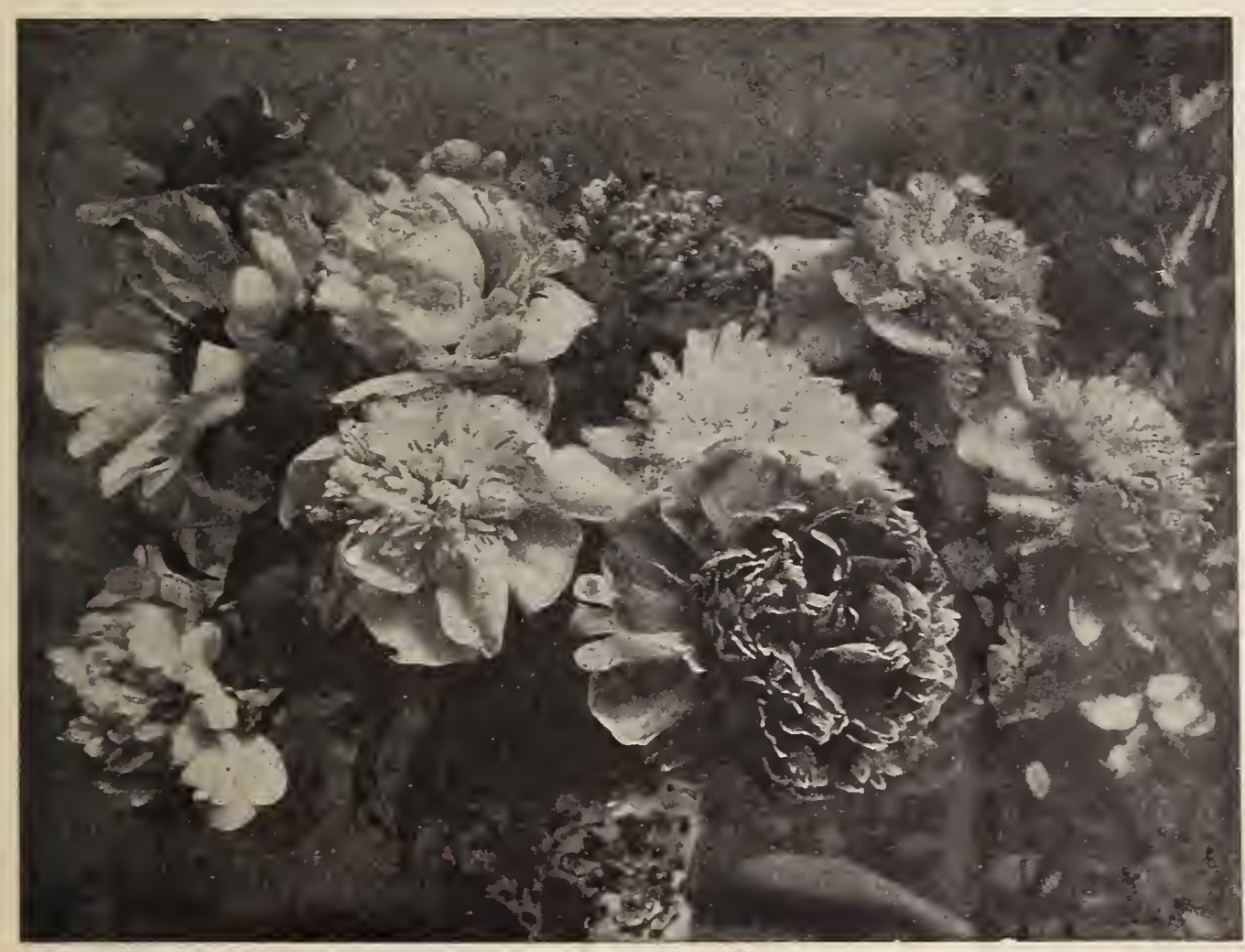

Pronias, Chinensis Types

NOTE MY ONLY ADDRESS: 342 WEST I4th STREET, NEW YORK CITY
Giant Double French. Mixed colors.

Double Persian. Mixed colors

Double Turban. Mixed colors.

\section{SCILLA}

Sibirica, or Præcox.

SPARAXIS

Choice Mixed Colors

\begin{tabular}{|c|c|}
\hline 100 & 1000 \\
\hline$\$ 050$ & $\$ 400$ \\
\hline 75 & \\
\hline
\end{tabular}

\begin{tabular}{|c|c|c|}
\hline & SNOWDROPS & \\
\hline Large, single & & $\begin{array}{r}\text { so } 75 \\
125 \\
75\end{array}$ \\
\hline
\end{tabular}

\section{PAEONIAS}

PAEONIA OFFICINALIS Doz. 100

Rubra. Deep crimson; can be forced for Easter. \$ $\$ 100 \quad \$ 700$ Alba. White arimer. 2001500 Rosea. Rose; also a good forcer.................. $175 \quad 1200$

\section{PAEONIA CHINENSIS}

Double White Varieties " Pink Varjeties. Red Varieties.

D: $\mathbf{z}_{\mathbf{2}} \quad 100$

$\$ 1350$

$150 \quad 1000$

Case containing 67 Double White, 66 Double Red, 67 Double Pink Pæonias-rery strong roots, 3 to 5 eres-200 in all, $\$ 25.00$ per case.

\section{PAEONIA FESTIVA MAXIMA}

The finest white Pæonia in cultivation. 50c. each; $\$ 5.00$ per

\section{JAPANESE TREE PAEONIAS}

Extra selected string plants, 10 distinct double varieties. $75 \mathrm{c}$. each; $\$ 6.00$ per dozen; $\$ 45.00$ per 100 .

\section{CYCAS REVOLUTA}

\section{(Dry Stems). \\ Cycas, or Sago Palm}

Fresh imported, true long leaf variety, in cases containing about $350 \mathrm{lbs}$, each 75 per cent. of the stems $1 / 2 \mathrm{lb}$. to $3 \mathrm{lbs}$ each; 25 per cent. 3 to 6 Ibs. each; or we will repack the cases on arriral, with stems of any size suitable to the customer's requirements. Delivery $\mathrm{M}$ [arch and Apri.

Per 10 lbs., 12c, per Ib.; $100 \mathrm{lbs}$. 10c. per 1b.; whole case, $71 / 2 \mathrm{c}$ per $1 \mathrm{~b}$.

\section{JAPANESE FERN BALLS \\ December Delivery}

Fern Balls, 7 to 9 inches in diameter. $\$ 3.50$ per doz.; $\$ 22.00$ per 100.

Smaller Sized Fern Ball, suitable for mail trade, 5 in. $\$ 2.00$ per doz. : $\$ 15.00$ per 100. 


\section{MY SPECIALTY "QUALITY” FLOWER SEEDS FOR FLORISTS}

\section{FOR LATE SUMMER AND AUTUMN SOWING}

\section{PANSIES}

My Pansy Seed during the past season gare unprecedented satisfaction and every order booked last rear was duplicated and increased this yeit. All the testimonials received mentioned specially the high grade of flowers--color, form and size of the individual blossoms. One customer said I could write the testimonial myself, and to use his own words, "could make it as strong as I liked." This rear, by adding improved types, intending customers can absolutely rely on a duplication of this season's success with increased satisfaction. Мry "mark" for this strain is "Challenge," and it is all the word denotes.

PANSY-BODDINGTON'S "CHALLENGE"

A mixture of the choicest strains of five leading pansy specialists of America and Europe. All large flowers of good substance in an infinite variety of color and markings. New crop seed ready July.

$$
\$ 5.00 \text { per oz.; } \$ 2.00 \text { per } 1 / 4 \text { oz.; 75c. per plit. }
$$

\section{UNSOLICITED TESTIMONIALS}

Saratoga, N. Y., March 1st, 1905.

Your "Challenge" Pansy Seed is the best I ever saw, both for rariety, size and substance. Send me one ounce in July.

Lenox, Mass., April 18th, 1905.

"Challenge" Pansies now in bloom are exceptionally good. Best strain I have ever tried. I want none better. Book my order for same amount Supt. John Sloane, Esq. Stockbridge, Mass.

Four "Challenge" Pansy Seed is the finest I have ever grown. V. P. WOOKEY

Gardener to S. W. Woodward, Esq. Rockaway, L. I., April 5, 1905.

We were immensels pleased with the quality of the " Challenge" Pansies. They were the onest varieties I have erer gotten from any seed
store. Duplicate my last year's order.
R. E. SEALY.

Four "Challenge" Pansy Seed has proved excellent. P. Please duplicate my order for July. Gardener to J. Pierpont IIorgan, Esq.

\section{Other Choice Varieties of Pansies to Name and Color}

\section{Giant Trinnardeau. Mammoth flower-}

ing and in a good range of color

Masterpiece (Frilled Pansy). Petals beau-

tifully waved. Exquisite colors

Giant Five-blotched. A choice strain

Cassier's's Giant. A fine strain of large

highly colored floters ...................

Bignot's Stained. Extra choice
ers, large and plenty of light colors

Giant IIme. Perret. A recent introduction by a celebrated French specialist. of

strong free growth. Tery profuse blooming and many fine shades of color. Especially rich in red shades.

Giant Fire King. Brilliant red-yellow,

with large brown eyes ....................

violet, top petals light blue ............

Giant Canary Bird. A fire-spotted yel-

low variety on yellow ground............. ered Pansy. Mixed (splendid variety): flower beautiful shades of pink, lilac, orange, rose, terra-cotta, chamois, etc..

Giant Bronze

Giant Emperor William. Ultramarine Giant Golden Queen. Bright yellow, no eje..

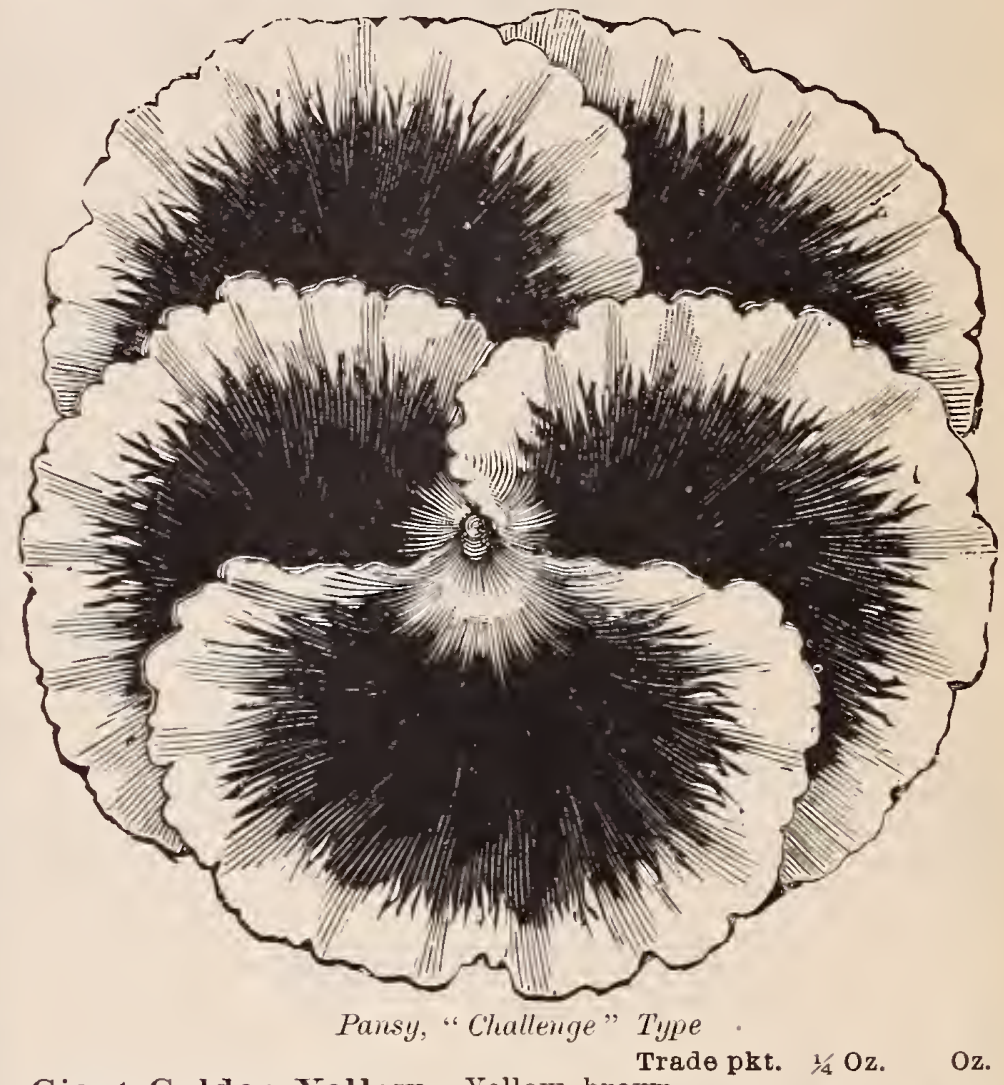

Giant Golden Yellow. Yellow, brown $\$ 040$ s0 75 \$2 50 Giant King of the Blacks (Faust).

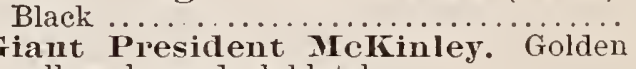
yellow, large dark blotch .................. Giant Prince Bismarck. Fellowish Giant Pretiosa. Crimson rose, white margin, violet blotch

Giant Rosy Lilac.

Giant Snow Queen. White center, tinged yellow

Giant Striped

Giant White. Violet spot; the largest white Giant Hydrangea Rose. Very distinct.
It is my policy and intention to disseminate only the very choicest strains of this class of Florists' Seeds and customers need have no hesitation in buying for fear of disappoictment when they bloom. No expense has been spared to secure the finest types as to habit of plant, form of flower and color, and breeding of my Quality Strains of Primula, Cineraria, Cyclamen and Calceolaria. I also recommend Schizanthus Wisetoniensis as pot plants for winter and spring flowering. See special notes on these two last named varieties.

\section{CINERARIA}

Boddington's Matchless Mixture is a combination of the three most famous English strains, which I can recommend to $25 \quad 125 \quad 400 \quad$ those wishing to grow the best. 'Tall, 1/ pkt. 60 cts.; pkt. $\$ 1.00$. $\begin{array}{llll}25 & 125 & 4 & 00\end{array} \quad$ those wishing to grow the best. Tall, 2 pkt. 60 cts.; pkt. $\$ 1.00$. Stellat a (Star-flowered Cineraria). Tall-growing: excellent as a single specimen for table decoration, or for grouping with splendid effect in corridors and conservatories. Pkt. 50 cts.; small pkt. 25 cts. 


\section{Quality Flower Seeds for Late Summer and Autumn Sowing-Continued}

\section{MIGNONETTE MAJESTY}

The finest of all fancy varieties of Mignonette; an improvement on "Allen's Defiance." Seed saved only from select spikes under glass.

Per Trade Pkt. of 2000 Seeds, \$1.00. Half Trade Pkt. " 1000 60.

\section{ANTIRRHINUM (Snapdragon)}

Very popular for Winter Flowering.

Giant Coral, red..

Daybreak, pink.

Brilliant., scarlet, sellow and so 20

"Crescia, dark scarlet, white, yellow ................

Mixed Giant varieties ................... 15

Dwarf Queen of the North, white... 15

Mixed Dwarf varieties.

\section{STOCKS}

Large-Flowering Ten Weeks' Sorts.

Boddington's selected strains are superior to all others.

Blood red..... Trade Pkt.

Canary yellow.

Bright rose.

Crimson

Light blue.

Purple.

Pure white.

Finest mixed

Tallflowered-leaved, Snowflake.

mixed. \$0 40

VARIOUS STOCKS

Empress Elizabeth

Princess Alice (Cut-and-Come-Again), white.

Brompton, mixed.

Intermediate, mixed.

Beauty of Nice (Daybreak

\section{PALM SEEDS}

Kentia Belmoreana.

$$
\text { Forsteriana }
$$

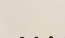

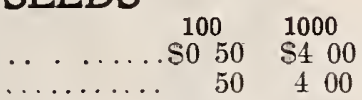

\section{SCHIZANTHUS WISETONIENSIS}

The handsomest and most showr Schizanthus to date. The colors are varied, ranging from white with yellow center to pin $k$ with brown center. Most useful as a winter plant, and should be given a place in every greenhouse. Trade pkt. 25 cts.

\section{RHODANTHE MANGLESI}

A little known plant, but very largely grown for the London Corent Garden Plant Market. Sow in 5 or 6 inch pots and thin out to about 20 plants. An intermediate temperature is all it requires. A most salable and attractive plant, pink or white. Trade Pkt., each 25 cts.

\section{THREE GRAND NEW CYCLAMEN}

\section{Cyclamen Persicum Giganteum Salmonium. A} new color for cyclamen, being of an intense salmon color; also good habit. Per trade pkt., $\$ 1.00$.

Cyclamen Persicum Giganteum Salmonium Splendens. Similar to the foregoing, only color more unique and intensified. Per trade pkt., \$1.00.

Cyclamen Persicum Giganteum Bush Hill Pioneer. A beautiful new feathered cyclamen in various colors. (See cut.) Per trade pkt., \$1.00.

\section{CYCLAMEN}

BODDINGTON'S GIGANTIC CYCLAMEN are unequaled for size or quality of bloom. A magnificent strain of Cyclamen with flowers of extraordinary size and substance. The leaves are proportionately large, and beautifully marked with silvergray.

Salmon Queen Pink. Undoubtedly the most distinct and beautiful color found in Cyclamen. Habit good and foliage handsomely marked.

Princess May. A very pretty type of Cyclamen. Color pink, with suffused blotches of crimson at base of petals.

Giant White. The largest of all white Cyclamen.

" Rose. Immense flowers of a pleasing shade of light rose.

" Rose. Immense flowers of a pleasing

" Crimson and White. A magnificent flower of the largest type.

"Crimson. Most striking color; under artificial light appears to be almost luminous.

“ Mixed. A mixture of all the above varieties in proper proportion.

Per pkt., 50c. ; per 100 seeds, $\$ 1.50$; per 1000 seeds, $\$ 12.00$.

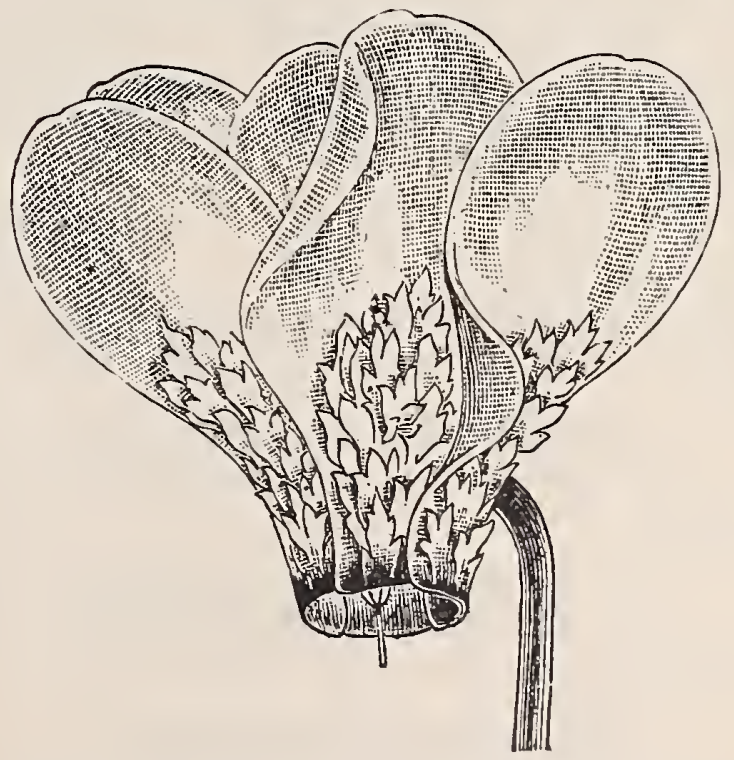

New Feathered Cyclamen, "Bush Hill Pioneer"

\section{SWEET PEAS FOR CHRISTMAS FLOWERING}

Sweet Peas (Christmas Early Pink). This is the earliest and most profitable and useful Sweet Pea in cultivation, as by sowing the seed under glass in latter part of August flowers san be cut from December on during the winter montlis. $60 \mathrm{c}$. per lb.; 15c. per oz.
Sweet Peas (Christmas Early White). A companion to Christmas Early Pink. Just as free and profuse a bloomer, and is, without doubt, the finest early white for indoor planting. 75c. per lb. ; 20c. per oz. 


\section{PI ANT DEPARTMETT TARDY HYBRID PERPETUAL, CRIMSON}

The right time to buy Roses, whether you need them in the spring or fall-is in the fall, when they are fresh and well ripened, and have not been laying in cold storage. Roses potted up in the fall or late winter become better established and force better, and are far more satisfactory in every way, and you can retard or force at your leisure.

I am handling this year American and Holland-grown stock, in Hybrids, Crimson Rambler and other Roses. MIore especially do I recommend the American-grown "Ramblers." Don't attempt to force imported Ramblers; the general experience is that they are a failure.
PRICES
AMERICAN-GROWN STOCK
Per 10
Per 100
Per 1000
ON H. P. ROSES
HOLLAND-GROWN STOCK -
$\$ 1.25$
11.00
110.00
100.00

\section{HARDY H. P. ROSES}

I offer exceptionally strong two-year-old dormant, lowbudded stock (on Manetti), in the following varieties:

Alfred Colomb. Carmine.

Anna de Diesbach. Bright carmine.

Ball of Snow. Pure white.

Baron de Bonstetten. Dark crimson, shaded.

Baroness Rothschild. Satiny pink; extra.

Captain Christy. Delicate flesh color.

Duke of Edinburgh. Bright vermilion; very fine.

Fisher Holmes. Dark rich scarlet.

General Jacqueminot. Rich velvety crimson.

General Washington. Beautiful red, shaded carmine.

John Hopper. Brilliant rose-pink.

La France. The finest light pink.

Margaret Dickson. White, pale flesh center.

Magna Charta. Clear rosy pink.

Ime. Gabriel Luizet. Light, satiny pink.

Mme. Plantier. White.

Mrs. John Laing. Soft pink; most desirable variety.

Paul Neyron. Beautiful dark pink.

Prince Camille de Rohan. Velvety crimson.

Ulrich Brunner. Cherry red.

\section{HYBRID TEA ROSES}

Maman Cochet, pink. Maman Cochet, white. Two truly magnificent Roses, unequaled as a bedders for summer blooming. They are very vigorous growers, producing buds of large size and of ideal form. The buds are of the color and form of Bridesmaid and Bride, but larger, and outside will yield more blooms than the latter will do under glass. The two finest outdoor Roses yet introduced. Strong 2-year-old plants, 10 for $\$ 1.50 ; \$ 12.00$ per 100 .

American Beauty, Clothilde Soupert, Kaiserin Augusta Victoria, Caroline Testout, Hermosa. Strong, 2-year-old, \$15.00 per 100.

MANETTI STOCKS FOR GRAFTING Selected English stock, best quality, $\$ 2.00$ per $100 ; \$ 15.00$ per 1000 .

\section{CRIMSON RAMBLER}

American-Grown-The Only Stock for Forcing

Large heary plants, two years old, 3 to 5 feet, $\$ 2.00$ per 10 . $\$ 15.00$ per 100 .

\section{ACACIA PUBESCENS}

Fire-inch pots, about three feet high, four years old, $\$ 5.00$ each; $\$ 55.00$ per doz.

\section{LORRAINE BEGONIA}

Gloire de Lorraine, 21/2 inch pots, $\$ 15.00$ per 100 .

\section{AZALEA MOLLIS}

Most attractive in the shrubbery; also extensively forced on account of the brilliancy of colors. $\$ 7.50$ per doz.; $\$ 55.00$ per 100 .

\section{THE KILLARNEY ROSE.}

The unprecedented demand for this rose last Spring has induced me to purchase a fine stock of two-year-old field-grown plants from the originators in Ireland. This rose is equally useful for summer flowering or winter blooming under glass. Culor beautiful "Testout" pink. Buds very long-blooms cut will last a week to ten days. Good strong two-year-old plants, \$3.00 per $10 ; \$ 25.00$ per 100 .

\section{THE BABY RAMBLER}

Mne. Norbert Levarasseur. This rose, next to the Rambler, is one of the most important acquisitions of recent years in the line of Hardy fioses. For a continuous bloomer in pets or as a bedder it is scarcely equaled by anything in the plant line. Strong field-grown plants, $\$ 3.00$ per $10 ; \$ 25.00$ per 100 .

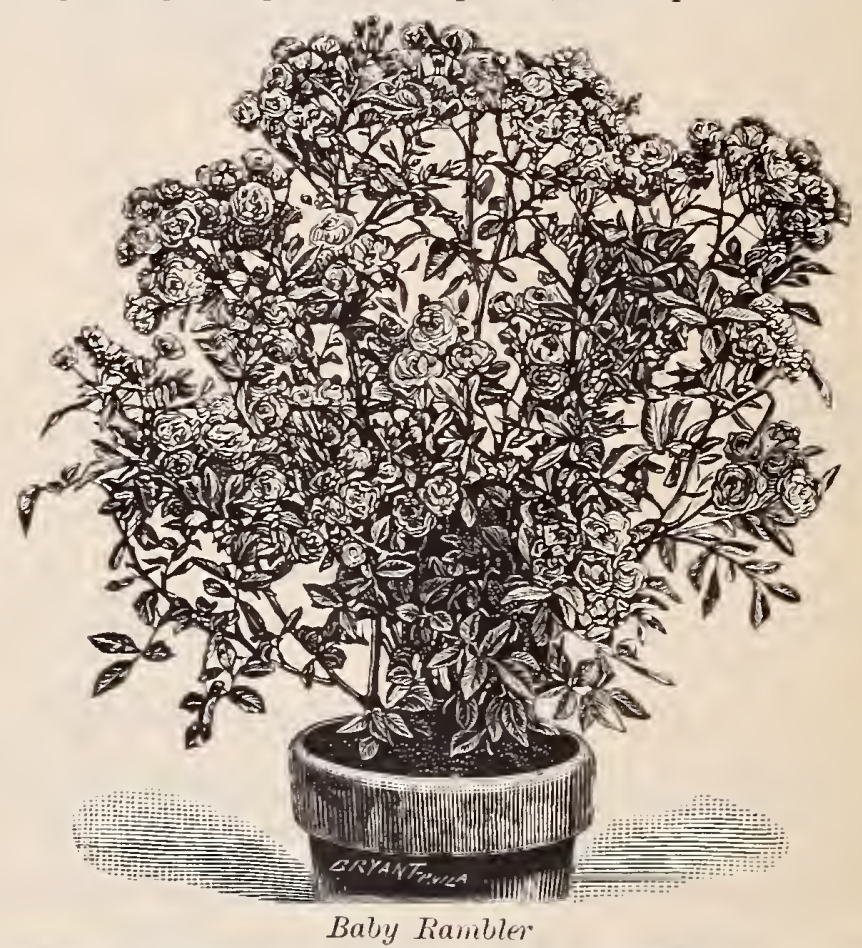

\section{DEUTZIA}

Gracillis, pot-grown for forcing, $\$ 2.00$ per doz.; $\$ 15.00$ per 100 Lemoinei,

\section{LILACS}

For forcing, pot-grown; November delivery; extra strong plants, well set with buds: Charles X. Reddish purple flowers.......... \$6.50 $\$ 50.00$ Marie Legraye. Single white.............. $6.50 \quad 50.00$ Mme. Casimir Perier. Double white..........6. $6.50 \quad 5000$ Mme. Lemoine. Double white............. 6.50 50.00

I am the Sole Agent of Pynaert Van Geert, Ghent, Belgium, for his specialties-Azaleas. Palms, Araucarias, Bay Trees, etc., and will send his catalogue upon application, or quote you speciai prices on any article you may need. His goods are well-known and I can attach my trade mark "Quality" to his stock with the same assurance that I would to my own. 


\section{FLORISTS ${ }^{\dagger}$}

Bellows, Woodason's (Powder).

Single cone, large, each.

S1 75

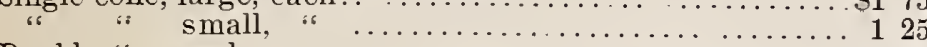

Double " each.

$2 \frac{1}{75}$

Cane Stakes. Japanese Bamboo. Far superior to the Southern Cane Stakes, being very thin and rery strong. 5 to $6 \mathrm{ft}$. long. $\$ 6.00$ per 1000 . 2000 for $\$ 10.00$

Carnation Supports.

Model, 2 ring

$\$ 2.50$ per $100 ; \$ 22.00$ per 1000

Fumigators, Eureka, Galvanized.

No. 2. Holds 1 peck of stems.

No. 3. " $1 / 2$ bush.

S1 85

250

Glazing Points. Per lb. 36c.; 6 lbs. $\$ 2.00$.

Hose Mender's.

Hudson's, 6 tubes, 20 bands, 1 pair pliers, 65c.; by mail...S0 75 Cooper (brass), 8c....................... per doz.

Jones', oc.

Standard, 8c.

“ $\quad 59$

Mastica. Per gal. $\$ 1.25 ; 6$ gals. $\$ 7.00 ; 10$ gals. $\$ 11.25$; 22 gals. $\$ 23.40$.

Mastica Machine, $\$ 1.25 ; 5$ for $\$ 5.50$.

Pot Labels. In lots of 5000 we allow a discount of 5 per cent. Per 1000

Wooden, 4 inch, plain $10,000, \$ 4.50 ;$ S0 55

$\begin{array}{lr}\text { " } & 5 \\ \because & 5 \\ \text { “ } & 8 \\ \text { “ } & 10 \\ \text { " } & 12 \\ \text { “ } & 31 \\ \text { " } & 31 \\ & 31\end{array}$

4
5

painted. ........ $10,000,6.50$

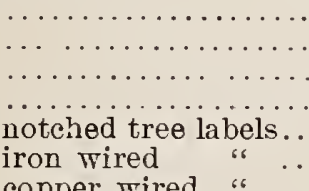

iron wired

copper wired lain painted

$\begin{array}{rrrr} & & \text { S0 } & 75 \\ 75 & 1 & 00 \\ 90 & 1 & 25 \\ 3 & 00 & 3 & 80 \\ & & 4 & 75 \\ 4 & 50 & 5 & 60 \\ 55 & & 75 \\ 85 & & 1 & 00 \\ 1 & 10 & & 1 \\ 1 & 30\end{array}$

\section{SUNDRIES}

Plant Stakes. Wooden, Green. Handsome and conrenient for gladiolus, etc.

Light, $1 \frac{1}{2} \mathrm{ft}$.

Per 100

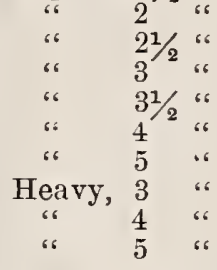

155

$\begin{array}{lll}1 & 30\end{array}$

310

$\begin{array}{ll}3 & 90\end{array}$

$+70$

540

465

575

Raffia. 1 lb., 20c; 10 lbs., \$1.45; 100 lbs., \$11.00; full bale of 250 lbs. at $\$ 10.75$ per $100 \mathrm{lbs}$.

Rubber Garden Hose.

Wire wrapped, 3 ply. $3 / 4$ in

Fine quality 3 " 3 "

Extra “ $\quad 3$ " $43 / \frac{3}{3}$ " "

So 15

Silkaline. For stringing smilax, etc., fast green colors, will not fade or break.

FFF Coarse, 2 oz. spools, 1 lb. in box, 8 spools.........\$1 25

FF Medium, 2 oz. " " "

F Fine, 2 oz. " " " " "

Tubs. Boddington's flower and tree tubs are made from everlasting cypress. Painted green. Castings japanned. Feet and bolts packed inside tubs to facilitate nesting for shipping.

No. Diam. Height $\quad$ Bottom

$1 \quad 13 \frac{1}{2}$ in. $\quad 11 \frac{1}{2}$ in. $\quad 11 \frac{1}{2}$ in. $\quad$ So 75

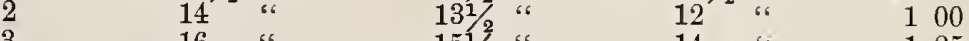

$\begin{array}{lllllll}3 & 16 & 6 & 151 \% \text { “ } & 14 & 1 & 125 \\ 4 & 20 & 18 & 18 & 18 & 180\end{array}$

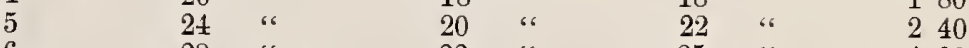

28 "، 22 " 2000

Twemlow's Old English Glazing Putty. Semi-liquid. To be used in the same manner as Mastica. Per gal. $\$ 1.25 ; 5$ gals. $\$ 5.50$.
Pulverized Sheep Manure. $\$ 1.50$ per $100 \mathrm{lbs}$; $\$ 25.00$ per ton Blood and Bone........... $\quad 2.50$

Bone Meal for Roses...... 2.50
35.00

35.00
Clay's Fertilizer......... 56 lb. bag $\$ 4.00 ; 112$ lb. bag $\$ 7.00$ Canada Hard Wood Ashes $\$ 3.00$ per 200 lbs.; \$22.50 per tion Nitrate of Soda..10 lbs. 50c.; 3.50 " 100 " 60.00 "

\section{INSECTICIDES}

Fir Tree Oil. 75c. per pt.; $\$ 1.40$ per qt.; $\$ 4.25$ per gal.

Flour of Sulphur. 60c. per $10 \mathrm{lbs}$; $5 \mathrm{c}$. per $1 \mathrm{lb}$. for $25 \mathrm{lbs}$. and over

Nicoticide. $\$ 2.50$ per pt.; sufficient for 32,000 eubic feet.

Fumigator for above, $75 \mathrm{c}$

Nikoteen. $\$ 1.50$ per pt. bottle; $\$ 13.00$ per case of 10 bottles.

Vaporizing pans for above, $\$ 1.50$ each ; $\$ 4.00$ for 3 .

Tobacco Stems. Bales of 100 lbs., \$1.25 : \$18.00 per ton.

Tobacco Dust. S3.00 per 100 lbs.
Whale Oil Soap. 18c. per lb; 40c. per 3-lb. box.

Nico-Fume Tobacco Paper. 24 sheets $75 c^{\circ}$; 14 sheets $\$ 3.50 ; 288$ sheets $\$ 6.50$.

Lemon Oil. 25c. 1/2 pt.; 40c. pt.; 75c. qt.; $\$ 1.25$ per $1 / 2$ gal. $\$ 2.00$ gal.; $\$ 9.005$ gals.

Extract of Tobacco. "Rose Leaf." Pt. can 30c.; qt. can 50c. gal. can $\$ 1.25 ; 5$-gal. can, $\$ 4.25$.

\section{MILLTRACK MUSHROOM SPAWN}

Fresh from the most celebrated maker in England. Made in bricks. $10 \mathrm{lbs}$ will spawn 10 feet square. Per lb., 15̌c.; 8 lbs. for $\$ 1.00 ; \$ 8.00$ per 100 lbs.

\section{PURE CULTURE MUSHROOM SPAWN}

Pure Culture Mushroom Spawn. The "new idea" is no longer in the experimental stage. The largest gruwers of mushrooms (and growers of large mushrooms, too), use the Pure Culture Spawn in the West and North west.

Pure Culture Mushroom Spawn is propagated by a scientific process direct from varieties selected for size and prolific bearing. By this new process, the chances of the spawn becoming "dead," and the crop a failure, are largely eliminated.
In Pure Culture Mushroom Spawn the idea of improvement has been carried out, as in the improvement of all the regetable kingdom, with regard to cropping and fitness for market purposes; and the difference is as noticeable, in comparison with any "wild" variety to a set and cultivated type now generally recognized, whether it be a fruit, flower or vegetable.

Price of Pure Culture Mushroom Spawn. Per lb., 15c.; $\$ 1.25$ per $10 \mathrm{lbs}$; ; $\$ 10.00$ per 100 lbs. 
How many customers did you turn away last year because you did not carry any bulbs to retail in a dormant state, such as Hyacinths, Tulips, Daffodils, Narcissus, Snowdrops, Crocus, etc., etc.?

Popular varieties of bulbs arranged attracticely in low pans or boxes, with prices and name attached, will make sales and interest your customers. If necessary, put a small "ad" in your local paper. Don't let the "dry goods" house crowd rou out of your legitimate business-it is yours-so go after it in a workmanlike aud businesslike manner. No, there are not "millions in it," but it will pay and pay you well. Let people see you are "up-to-date."

Belnw I have made a careful selection of a Special List of Bulbs suitable for the small customer and small sarden-the customer who has not the income to "own a greenhouse," ret one who likes to have a few spring flowers in his "front lot" or "back yard "or maybe, in his window.

On all orders of $\$ 25.00$ or over, I will send you free 500 nicely gotten up lists containing the following varieties, with retail prices attached, with your name and address printed thereon. This will help you and help me too, though my name does not appear in the list; it will increase the popularity and sale of Bulbs and Flowers and will make business, for us both. Don't shrug your shoulders and throw this down. Think it over and send a trial order. I am positive others will follow.

Special Mixed Hyacinths to Color for Bedding

SINGLE-

Crimson

Pink

Rose

Pure White

Blush IThite

Light Blue

Dark Blue

Tellow

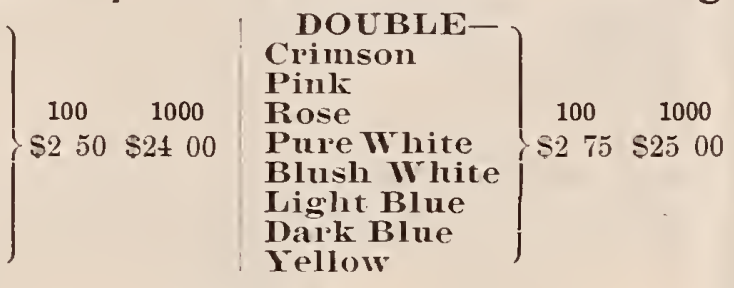

TULIPS

I recommend the following rarieties of tulips, to color, for bedding, as they grow and flower easily, and make an excellent show.

Red,

White,

Yellow

Striped,

Red and Yellow,

\section{SINGLE TULIPS}

$$
\text { to color.. }
$$

Red,

White,

Yellow.

Striped,

Red and Yellow,

\section{DOUBLE TULIPS}

to color...

\section{FINE MIXED SINGLE TULIPS \\ 60c. per $100 ; \$ 5.25$ per 1000 . \\ FINE MIXED DOUBLE TULIPS \\ $75 \mathrm{c}$. per $100 ; \$ 7.00$ per 1000}

PARROT, OR DRAGON TULIPS

Fine mixture, 75c. per 100; $\$ 7.00$ per 1000.

SINGLE LATE, OR MAY-FLOWERING TULIPS

Good mixture, $\$ 1.00$ per $100 ; \$ 9.00$ per 1000 .

\section{CHIONODOXA}

Luciliae.

\section{LILIUM CANDIDUM}

St. Joseph's, or Annunciation Lily...... 5 5 $00 \quad 4500$

\section{CROCUS (Large Bulbs)}

Mlbion. Blue, striped white ................ s0 50

Baron Von Brunow. Dark blue........... 50

David Rizzio. Deep purple............... 50

Mout Blanc. Pure white................... 50

Sir Walter Scott. White, lilac striped...... 50

Giant Golden Yellow.................. 50

Irixed Crocus. Separate colors-white, striped,

blue, variegated, yellow................... 25

\section{SINGLE NARCISSUS}

\begin{tabular}{|c|c|c|}
\hline & $\begin{array}{l}100 \\
\text { S175 }\end{array}$ & $\begin{array}{r}1000 \\
\$ 1500\end{array}$ \\
\hline Horsfieldii. & 175 & 1500 \\
\hline Golden Spur... & 200 & 175 \\
\hline Ajax Princeps. & 100 & 75 \\
\hline Poeticus ..... & 50 & \\
\hline Truinpet Majo & 125 & 10 \\
\hline
\end{tabular}

DOUBLE NARCISSUS, OR DAFFODILS

Alba Plena Odorata (Gardenia-flowered Daf- $100 \quad 1000$

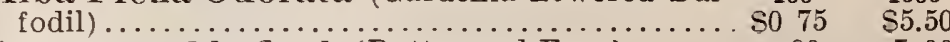

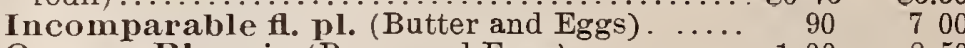

Orange Phoenix (Bacon and Eggs)............... $100 \quad 850$

Von Sion (True Double Daffodil). Selected bulbs. 1251000

Double Sweet-Scented JONQUILS

Single Sweet-Scented....................

Campernelle........................ $50 \quad 425$

Rugulosus.

\section{CHINESE SACRED NARCISSUS}

Per original basket of 30 bulbs, $\$ 1.25$; per mat of 120 bulbs, $\$ 4.50$; per $1000, \$ 35.00$.

\section{SPANISH IRIS (Iris Hispanica)}

Choicest mixed, all colors.................. \$ ${ }_{0}^{100} 35 \quad \$ 250$

\section{SNOWDROPS}

Large, single double.

75

Bulbs see body of this Catalogue.

\section{GRASS SEED FOR FALL SOWING}

I can supply my famous Lenox Lawn Grass Seed, put up in pint and quart packages, at $\$ 10.00$ per 100 quarts.

Can also supply Lenox Lawn Grasses in $1 / \frac{1}{4}$-bushel, $1 / 2$-bushel and 1-bushel sealed bags at the rate of $\$ 3.00$ per bushel.

\section{ARTHUR T. BODDINGTON}

\section{Note Hy Only Address -}

\section{WEST 14th STREET (Near 9th Avenue), NEW YORK}

